\title{
Cakile maritima Scop. extracts inhibit the growth of some bacterial triggers of autoimmune diseases: GC-MS analysis of an inhibitory extract
}

\author{
Elsayed Omer', Abdelsamed Elshamy ${ }^{2}$, Abdel Nasser El Gendy ${ }^{1}$, Xin Cai ${ }^{3,4}$, Joseph Sirdaarta ${ }^{4,5}$, Alan White ${ }^{4}$, lan Edwin Cock ${ }^{4,5^{*}}$ \\ 'Department of Medicinal and Aromatic Plants Research, National Research Centre, Dokki (12622), Giza, EGYPT. \\ 2Department of Chemistry of Natural Compounds, National Research Centre, Dokki (12622), Giza, EGYPT. \\ 3School of Pharmacy, Nanjing University of Chinese Medicine, Nanjing, CHINA. \\ ${ }^{4}$ School of Natural Sciences, Nathan Campus, Griffith University, 170 Kessels Rd, Nathan, Queensland 4111, AUSTRALIA. \\ 5Environmental Futures Research Institute, Nathan Campus, Griffith University, 170 Kessels Rd, Nathan, Queensland 4111, AUSTRALIA.
}

\begin{abstract}
Introduction: High antioxidant capacities have been linked to the treatment of rheumatic diseases and also in the inhibition of microbial growth. Although Cakile maritima has a high antioxidant capacity, it is yet to be tested for the ability to inhibit the growth of the bacterial triggers of autoimmune inflammatory diseases. Methods: C. maritima solvent extracts were analysed for antioxidant capacity by the DPPH free radical scavenging assay. Growth inhibitory activities against bacterial species associated with initiating rheumatoid arthritis, ankylosing spondylitis and multiple sclerosis were determined by disc diffusion assay and quantified by MIC determination. Toxicity was determined by Artemia franciscana bioassay. Results: All C. maritima solvent extracts displayed good DPPH radical scavenging activity, although the ethyl acetate extract was particularly potent with an $\mathrm{IC}_{50}$ values of $3.4 \mu \mathrm{g} / \mathrm{mL}$. The other extracts also had significant radical scavenging activity, with $\mathrm{IC}_{50}$ between 4.7 and $13.6 \mu \mathrm{g} / \mathrm{mL}$. The bacterial growth inhibitory activity of the extracts correlated with their free radical scavenging activity. The ethyl acetate extract displayed the most potent growth inhibitory activity against most bacterial species. This extract was particularly potent against Proteus mirabilis, Proteus vulgaris and Pseudomonas aeruginosa (MIC values of 431, 559 and $777 \mu \mathrm{g} / \mathrm{mL}$, respectively). The hexane extract was also a potent inhibitor of the Proteus spp., (MIC of approximately $500-800 \mu \mathrm{g} / \mathrm{mL}$ ). The ethyl acetate extract also inhibited Klebsiella pneumoniae growth, albeit with higher
\end{abstract}

MIC's (approximately $1500 \mu \mathrm{g} / \mathrm{mL}$ ). All other C. maritima extract-bacteria combinations generally resulted in mid-low potency inhibition. All of the extracts were determined to be nontoxicin with the Artemia franciscana bioassay, with $\mathrm{LC}_{50}$ values substantially $>1000 \mu \mathrm{g} / \mathrm{mL}$. A total of 97 unique mass signals were detected in the $C$. maritima ethyl acetate extract by nonbiased GC-MS headspace analysis. A number of terpenoids which may contribute to the therapeutic bioactivities of the extract were putatively identified. Conclusion: The lack of toxicity and the inhibitory activity against microbial triggers of rheumatoid arthritis, ankylosing spondylitis and multiple sclerosis by the $C$. maritima ethyl acetate extract indicates its potential in the treatment and prevention of these diseases.

Key words: Rheumatoid arthritis, Ankylosing spondylitis, Multiple sclerosis, Proteus mirabilis, Proteus vulgaris, Klebsiella pneumoniae, Acinitobacter baylyi, Pseudomonas areuginosa.

Corresponding author: Ian Edwin Cock, School of Natural Sciences, Nathan Campus, Griffith University, 170 Kessels Rd, Nathan, Queensland 4111, AUSTRALIA.

Phone no: No: +61 7 37357637; Fax No: +61 737355282

Email: I.Cock@griffith.edu.au (I. E. Cock)

DOI : $10.5530 /$ pj.2016.4.9

\section{INTRODUCTION}

Cakile maritima Scop. (European sea rocket) is a common annual herb of the Brassicaceae (mustard) family. It is widespread throughout Europe and northern Africa in sandy, coastal regions. It has also been introduced to many areas globally. Due to its vigorous growth in harsh environments, it has often displaced native taxa and become widely naturalised internationally. It grows as a small shrub to $40 \mathrm{~cm}$ high with a multi-branched stem. The succulent/fleshy leaves are alternate with long pinnate lobes. Light purple to white inflorescence racemes develop in the warmer summer months. These develop into small $(1.5-2 \mathrm{~cm})$, flat, segmented fruit containing 2 seeds. The seed pods float and are water dispersed.

All parts of the plant are reputed to have a high antioxidant capacity and are particularly rich in ascorbic acid. ${ }^{1}$ The leaves, stems, flowers and immature fruit have been consumed in areas in which they grow, particularly when other food sources are scarce. ${ }^{2}$ Traditionally, C. maritima has been used as a flavouring agent, although young raw leaves may be added to salads. A powder prepared from the dried ground root can be mixed with cereal flours to make bread. Furthermore, due to its high antioxidant capacity, C. maritima has potential for the treatment of multiple diseases. Oxidative stress is associated with many human diseases including cancer, chronic inflammation, atherosclerosis and Alzheimer's disease. ${ }^{3}$ Individuals with elevated dietary intakes of non-enzymatic antioxidants such as vitamins A, C and E are less likely to suffer from some diseases including cancer and chronic inflammation. ${ }^{4}$ Furthermore, several studies have demonstrated bacterial growth inhibitory and anti-infammatory activities for several culinary plants with high antioxidant capacities, and have linked the bioactivities to their free radical scavenging activities. ${ }^{5-9}$ Despite this, we were unable to find reports examining the antibacterial and anti-infammatory activities of C. maritima.

Autoimmune inflammatory disorders (e.g. rheumatoid arthritis, ankylosing spondylitis, multiple sclerosis) are a group of debilitating conditions which afflict genetically susceptible individuals. There are no cures for any of these conditions. Instead, current treatment strategies aim to alleviate the symptoms (particularly pain, swelling and inflammation) with analgesics and anti-inflammatory agents and/or to modify the disease process through the use of disease modifying drugs. None of these treatments is ideal as prolonged usage of these drugs is often accompanied by unwanted side effects and toxicity. ${ }^{10}$ There is a need to develop safer, more effective treatments for these conditions which will not only alleviate the symptoms, but may also cure or prevent the disease. A greater understanding of the onset and progression of these disorders should greatly assist in more relevant drug discovery and development. The causes of autoimmune inflammatory disorders are currently not comprehensively understood although it is generally accepted that they 
are immune disorders triggered in susceptible individuals by specific microbial infections. Serotyping studies have identified several of the bacterial triggers of some of these conditions and the bacterial antigens responsible for the induction of an immune response (Table 1). A major microbial trigger of rheumatoid arthritis has been identified as P. mirabilis, ${ }^{11}$ a normal part of the human gastrointestinal flora. Similarly, K. pneumoniae has been shown to initiate ankylosing spondylitis ${ }^{12}$ and $A$. baylyi and $P$. aeruginosa have been linked with the onset of multiple sclerosis. ${ }^{13}$ Borrelia burgdorferi is linked with Lyme disease. ${ }^{14}$ Whilst microbial triggers have also been postulated for lupus, the specific causative agents are yet to be identified. Similarly, members of the Enterobacteriaceae family are associated with Graves' disease and Kawasaki syndrome and Mycoplasma pneumoniae is associated with several demyelinating diseases. ${ }^{15}$ The development of antibiotic agents targeted at the specific bacterial triggers of autoimmune inflammatory disorders would enable afflicted individuals to target these microbes and thus prevent the onset of the disease and reduce the severity of the symptoms once the disease has progressed.

A re-examination of traditional medicines for the treatment of inflammation and rheumatic conditions is an attractive prospect as the antiseptic qualities of medicinal plants have also been long recognised and recorded. Furthermore, there has recently been a revival of interest in herbal medications due to a perception that there is a lower incidence of adverse reactions to plant preparations compared to synthetic pharmaceuticals. Antimicrobial plant extracts with high antioxidant contents are particularly attractive as they may treat the symptoms of inflammation as well as blocking the microbial trigger and thus have pleuripotent effects. The current study was undertaken to examine the growth inhibitory activity of $C$. maritima extracts against bacterial species associated with the onset of selected autoimmune diseases.

\section{MATERIALS AND METHODS}

\section{Plant material}

The aerial parts of Cakile maritima Scop. were collected and identified by Dr. Ahmed M. Abd El-Gawad, from Kafr-Saad, Damietta Governorate, Egypt in April 2015. A voucher specimen (Code No: CAM-311-015) was deposited at the herbarium of the Botany Department, Faculty of Science, Mansoura University, Egypt.

\section{Preparation of extracts}

The air-dried aerial parts of C. maritima Scop. (1 kg) were pulverized then macerated in $70 \%$ methanol $(5 \mathrm{~L})$ at room temperature for five days, filtered, and evaporated under vacuum to give dark black extract (58 g). The dry alcoholic extract was dissolved in distilled water $(1 \mathrm{~L})$ and then successively fractionated using $n$-hexane, ethyl acetate and methanol, respectively ( $0.5 \mathrm{~L}$ three times). Each fraction was separately dried under vacuum to yield $10.5,15.0$ and $32.5 \mathrm{gm}$, respectively.

\section{Qualitative phytochemical studies}

Phytochemical analysis of the different plant extracts for the presence of saponins, phenolic compounds, flavonoids, phytosteroids, triterpenoids, cardiac glycosides, anthraquinones, tannins and alkaloids was conducted by previously described assays..$^{25-27}$

\section{Antioxidant capacity determination}

The antioxidant capacity of each sample was assessed using the DPPH free radical scavenging method ${ }^{28}$ with modifications. Briefly, DPPH solution was prepared fresh each day as a $400 \mu \mathrm{M}$ solution by dissolving DPPH (Sigma) in AR grade methanol (Ajax, Australia). The initial absorbance of the DPPH solution was measured at $515 \mathrm{~nm}$ using a Molecular Devices, Spectra Max M3 plate reader and did not change significantly throughout the assay period. The test extracts were diluted in methanol (AR grade, Ajax, Australia) across the concentration range $10-80 \mu \mathrm{g} / \mathrm{mL}$. Aliquots $(20 \mu \mathrm{L})$ of each extract were mixed with $80 \mu \mathrm{L}$ of $100 \mathrm{mM}$ Tris- $\mathrm{HCl}$ buffer ( $\mathrm{pH}$ 7.4). A volume of $100 \mu \mathrm{L}$ of $\mathrm{DPPH}$ solution was added to each well to give a volume of $250 \mu \mathrm{L}$. The assays mixtures were mixed vigorously and left to stand in the dark for $20 \mathrm{~min}$ at $23^{\circ} \mathrm{C}$. A blank of each extract concentration, methanol solvent, and DPPH was also performed in triplicate. Ascorbic acid was prepared fresh and examined across the range $0-25 \mu \mathrm{g}$ per well as a reference and the absorbances were recorded at $515 \mathrm{~nm}$. All tests were performed in triplicate and triplicate controls were included on each plate. The \% DPPH decolourisation was calculated using the following formula:

$$
\% \text { decolorisation }=[1-(\text { Atest } / \text { Acontrol })] \times 100
$$

As a measure of antioxidant capacity, $\mathrm{IC}_{50}$ values were determined as the test concentration capable of scavenging $50 \%$ of the DPPH radicals via linear regression.

\section{Antibacterial screening}

\section{Test microorganisms}

All media was supplied by Oxoid Ltd. Reference strains of Acinitobacter baylyi (ATCC33304), Klebsiella pneumoniae (ATCC31488), Proteus mirabilis (ATCC21721), Proteus vulgaris (ATCC21719) and Pseudomonas aeruginosa (ATCC 39324) were purchased from American Tissue Culture Collection, USA. All stock cultures were subcultured and maintained in nutrient broth at $4^{\circ} \mathrm{C}$.

\section{Evaluation of antimicrobial activity}

Antimicrobial activity of all plant extracts was determined using a modified disc diffusion assay. ${ }^{29-31}$ Briefly, $100 \mu \mathrm{L}$ of the test bacteria were grown in $10 \mathrm{~mL}$ of fresh nutrient broth media until they reached a count of approximately $10^{8}$ cells $/ \mathrm{mL}$. An amount of $100 \mu \mathrm{L}$ of bacterial suspension was spread onto nutrient agar plates. The extracts were tested for antibacterial activity using $5 \mathrm{~mm}$ sterilised filter paper discs. Discs were infused with $10 \mu \mathrm{L}$ of the test sample, allowed to dry and placed onto inoculated plates. The plates were allowed to stand at $4^{\circ} \mathrm{C}$ for $2 \mathrm{~h}$ before incubation with the test microbial agents. Inoculated plates were incubated at $30^{\circ} \mathrm{C}$ for $24 \mathrm{~h}$, and then the diameters of the inhibition zones were measured in millimetres. All measurements were to the closest whole millimetre. Each antimicrobial assay was performed in at least triplicate. Mean values $( \pm$ SEM) are reported in this study. Standard discs of ampicillin $(10 \mu \mathrm{g})$ were obtained from Oxoid Ltd., Australia and served as positive controls for antibacterial activity. Filter discs infused with $10 \mu \mathrm{L}$ of distilled water were used as a negative control.

\section{Minimum inhibitory concentration (MIC) determination}

The minimum inhibitory concentrations (MIC) of the extracts were determined as previously described. ${ }^{29,30}$ Briefly, the plant extracts were diluted in deionised water and tested across a range of concentrations. Discs were infused with $10 \mu \mathrm{L}$ of the test dilutions, allowed to dry and placed onto inoculated plates. The assay was performed as outlined above and graphs of the zone of inhibition versus concentration were plotted for each extract. Linear regression was used to calculate the MIC values.

\section{Toxicity screening}

\section{Reference toxin for toxicity screening}

Potassium dichromate $\left(\mathrm{K}_{2} \mathrm{Cr}_{2} \mathrm{O}_{7}\right)$ (AR grade, Chem-Supply, Australia) was prepared as a $1.6 \mathrm{mg} / \mathrm{mL}$ solution in distilled water and was serially 
Table 1: The bacterial triggers of the selected autoimmune inflammatory diseases as well as the bacterial antigen and host susceptibility antigen sequences

\begin{tabular}{|c|c|c|c|c|c|c|}
\hline Disease & Bacterial Trigger & Bacterial Antigen & Bacterial Sequence & Host Antigen & Host Sequence & References \\
\hline \multirow[t]{2}{*}{ Rheumatoid arthritis } & $\begin{array}{l}\text { Proteus mirabilis and } \\
\text { possibly also other }\end{array}$ & haemolysin & ESRRAL & $\begin{array}{l}\text { MHC class } 2 \text { allele } \\
\text { HLA-DR4 }\end{array}$ & EQ/KRRAA & $11,12,16$ \\
\hline & Proteus spp. & urease & IRRET & type XI collagen & LRREI & 17,18 \\
\hline \multirow{3}{*}{$\begin{array}{l}\text { Ankylosing } \\
\text { spondylitis }\end{array}$} & & $\begin{array}{l}\text { nitrogenase } \\
\text { reductase enzyme }\end{array}$ & QTDRED & $\begin{array}{l}\text { MHC class } 1 \text { allele } \\
\text { HLA-B27 }\end{array}$ & QTDRED & 11,19 \\
\hline & $\begin{array}{l}\text { Klebsiella } \\
\text { pneumoniae }\end{array}$ & pullulanase & DRDE & $\begin{array}{l}\text { MHC class } 1 \text { allele } \\
\text { HLA-B27 }\end{array}$ & DRED & 20 \\
\hline & & pullulanase & $\mathrm{GxP}$ & $\begin{array}{l}\text { types I, III and IV } \\
\text { collagen }\end{array}$ & $\mathrm{GxP}$ & 21 \\
\hline \multirow{4}{*}{ Multiple sclerosis } & $\begin{array}{l}\text { Pseudomonas } \\
\text { aeriginosa }\end{array}$ & $\Upsilon$-CMLD & TRHAYG & $\begin{array}{l}\text { Myelin-neuronal } \\
\text { antigen MBP }\end{array}$ & SRFSYG & 22 \\
\hline & & 4-CMLD & SRFAYG & $\begin{array}{l}\text { Myelin-neuronal } \\
\text { antigen MBP }\end{array}$ & SRFSYG & 22 \\
\hline & Acinetobacter spp. & 3-OACT-A & LTRAGK & $\begin{array}{l}\text { Myelin-neuronal } \\
\text { antigen MOG }\end{array}$ & LYRDGK & 22 \\
\hline & & $\begin{array}{l}\text { Acinetobacter } \\
\text { regulatory protein }\end{array}$ & ${ }^{\star} \mathrm{KKVEEI}$ & $\begin{array}{l}\text { Neurofilament-M } \\
\text { protein }\end{array}$ & ${ }^{\star}$ KKVEEI & $22-24$ \\
\hline
\end{tabular}

MOG = myelin oligodendrocyte glycoprotein; $\mathrm{MBP}=$ myelin basic protein; 4-CMLD = 4-carboxy-muconolactone decarboxylase; 3-OACT-A = 3-oxoadipate CoAtransferase; $\Upsilon$-CMLD $=\Upsilon$-carboxy-muconolactone decarboxylase. ${ }^{*}$ indicates the sequence likely to be responsible for cross-reactivity, although this is yet to be confirmed.

Table 2: The mass of dried extracted material, the concentration after resuspension in deionised water, qualitative phytochemical screenings and antioxidant capacities of the C. maritima extracts

\begin{tabular}{|c|c|c|c|c|c|c|c|c|c|c|c|c|c|c|c|c|}
\hline $\mathrm{TE}$ & 58 & 58 & 6.8 & NT & NT & NT & NT & NT & NT & NT & NT & NT & NT & NT & NT & NT \\
\hline CMM & 32.5 & 40 & 4.7 & +++ & +++ & ++ & - & + & + & + & + & + & +++ & - & - & - \\
\hline CME & 15.0 & 10 & 3.4 & +++ & ++ & ++ & - & + & + & - & - & - & ++ & - & - & - \\
\hline
\end{tabular}

+++ indicates a large response; ++ indicates a moderate response; + indicates a minor response; - indicates no response in the assay; NT = not tested. CMM = methanolic C. maritima extract; $\mathrm{CME}=$ ethyl acetate C. maritima extract; $\mathrm{CMH}=$ hexane C. maritima extract. Antioxidant capacity was determined by DPPH reduction and is expressed as the test concentration capable of scavenging $50 \%$ of the DPPH radical.

Table 3: The MIC values $(\mu \mathrm{g} / \mathrm{mL})$ of $C$. maritima extracts against bacterial triggers of autoimmune inflammatory diseases, and the LC50 values ( $\mu \mathrm{g} /$ $\mathrm{mL}$ ) in the Artemia franciscana nauplii bioassay

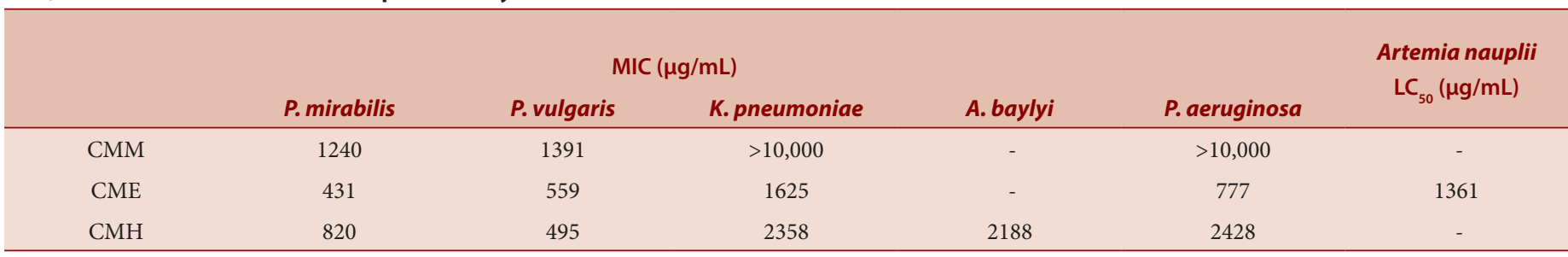

Numbers indicate the mean MIC or $\mathrm{LC}_{50}$ values of at least triplicate determinations. - indicates no bacterial growth inhibition or no significant brine shrimp mortality was evident. $\mathrm{CMM}=$ C. maritima methanolic extract; $\mathrm{CME}=$ C. maritima ethyl acetate extract; $\mathrm{CMH}=$ C. maritima hexane extract; $\mathrm{PC}=$ positive control $($ cisplatin for antiproliferative assays; potassium dichromate for toxicity assays). 
Table 4: Qualitative headspace GC-MS analysis of the ethyl acetate C. maritima extract, elucidation of empirical formulas and putative identification of the compounds.

\begin{tabular}{|c|c|c|c|c|}
\hline $\begin{array}{l}\text { Retention Time } \\
\quad(\min )\end{array}$ & Molecular Mass & Empirical Formula & Area $\%$ & Putative Identification \\
\hline 11.755 & 112 & $\mathrm{C}_{7} \mathrm{H}_{12} \mathrm{O}$ & 0.36 & (E)-2-Hepten-1-al \\
\hline 12.33 & 126 & $\mathrm{C}_{9} \mathrm{H}_{18}$ & 0.08 & 2,5,5-Trimethyl-1-hexene \\
\hline 12.616 & 162 & $\mathrm{C}_{6} \mathrm{H}_{10} \mathrm{O}_{5}$ & 0.39 & 3,4-Anhydrohexopyranose \\
\hline 12.738 & 126 & $\mathrm{C}_{8} \mathrm{H}_{14} \mathrm{O}$ & 0.84 & 6-Methyl-5-heptene-2-one \\
\hline 12.93 & 166 & $\mathrm{C}_{11} \mathrm{H}_{18} \mathrm{O}$ & 0.38 & Homomyrtenol \\
\hline 13.241 & 142 & $\mathrm{C}_{10} \mathrm{H}_{22}$ & 0.63 & Decane \\
\hline 13.54 & 142 & $\mathrm{C}_{10} \mathrm{H}_{22}$ & 0.04 & 3,3,5-Trimethylheptane \\
\hline 13.679 & 142 & $\mathrm{C}_{10} \mathrm{H}_{22}$ & 0.13 & 2,5,5-Trimethylheptane \\
\hline 13.845 & 120 & $\mathrm{C}_{9} \mathrm{H}_{12}$ & 0.15 & p-Methylethylbenzene \\
\hline 13.96 & 142 & $\mathrm{C}_{10} \mathrm{H}_{22}$ & 0.29 & 3,3,5-Trimethylheptane \\
\hline 14.095 & 136 & $\mathrm{C}_{10} \mathrm{H}_{16}$ & 0.65 & D-Limonene \\
\hline 14.632 & 166 & $\mathrm{C}_{10} \mathrm{H}_{22}$ & 0.21 & 1,1,3-Trimethyl-3-(2-methyl-2-propenyl)cyclopentane \\
\hline 14.866 & 138 & $\mathrm{C}_{10} \mathrm{H}_{18}$ & 0.62 & Decahydronaphthalene \\
\hline 14.993 & 154 & $\mathrm{C}_{11} \mathrm{H}_{22}$ & 0.15 & 1-Ethyl-2-propylcyclohexane \\
\hline 15.081 & 184 & $\mathrm{C}_{13} \mathrm{H}_{28}$ & 0.55 & 4,7-Dimethylundecane \\
\hline 15.269 & 198 & $\mathrm{C}_{14} \mathrm{H}_{30}$ & 0.45 & 4,6-Dimethyldodecane \\
\hline 15.473 & 184 & $\mathrm{C}_{13} \mathrm{H}_{28}$ & 0.38 & 5-Sec-butylnonane \\
\hline 15.744 & 172 & $\mathrm{C}_{11} \mathrm{H}_{24} \mathrm{O}$ & 0.16 & 2-Isopropyl-5-methyl-1-heptanol \\
\hline 15.86 & 168 & $\mathrm{C}_{12} \mathrm{H}_{24}$ & 0.6 & 1-Methyl-2-pentylcyclohexane \\
\hline 15.964 & 224 & $\mathrm{C}_{16} \mathrm{H}_{32}$ & 0.23 & Trans-1-methyl-2-nonyl-cyclohexane \\
\hline 16.242 & 154 & $\mathrm{C}_{8} \mathrm{H}_{10} \mathrm{O}_{3}$ & 0.44 & 1-(2-Furyl)-3-butene-1,2-diol \\
\hline 16.318 & 154 & $\mathrm{C}_{10} \mathrm{H}_{18} \mathrm{O}$ & 2.69 & Linalool \\
\hline 16.39 & 156 & $\mathrm{C}_{11} \mathrm{H}_{24}$ & 5.79 & Undecane \\
\hline 16.637 & 156 & $\mathrm{C}_{10} \mathrm{H}_{20} \mathrm{O}$ & 0.99 & Levomenthol \\
\hline 16.922 & 186 & $\mathrm{C}_{12} \mathrm{H}_{26} \mathrm{O}$ & 1.4 & 2-Butyl-1-octanol \\
\hline 17.131 & 152 & $\mathrm{C}_{11} \mathrm{H}_{20}$ & 1.28 & 2-Methyldecahydronaphthalene \\
\hline 17.223 & 184 & $\mathrm{C}_{13} \mathrm{H}_{28}$ & 0.67 & 5-Methyl-5-propylnonane \\
\hline 17.405 & 238 & $\mathrm{C}_{17} \mathrm{H}_{34}$ & 1.44 & (1-Methyldecyl)cyclohexane \\
\hline 17.753 & 184 & $\mathrm{C}_{13} \mathrm{H}_{28}$ & 0.12 & 2,3,5-Trimethyldecane \\
\hline 17.838 & 224 & $\mathrm{C}_{16} \mathrm{H}_{32}$ & 0.45 & Trans-1-methyl-2-nonyl-cyclohexane \\
\hline 17.902 & 114 & $\mathrm{C}_{8} \mathrm{H}_{18}$ & 0.32 & 3,3-Dimethylhexane \\
\hline 18.087 & 156 & $\mathrm{C}_{11} \mathrm{H}_{24}$ & 1.95 & Undecane \\
\hline 18.334 & 168 & $\mathrm{C}_{12} \mathrm{H}_{24}$ & 2.84 & 4-Methyl-1-undecene \\
\hline 18.527 & 254 & $\mathrm{C}_{18} \mathrm{H}_{38}$ & 1.7 & 9-methylheptadecane \\
\hline 18.611 & 152 & $\mathrm{C}_{11} \mathrm{H}_{20}$ & 0.14 & 1-Methyldecahydronaphthalene \\
\hline 18.75 & 184 & $\mathrm{C}_{13} \mathrm{H}_{28}$ & 0.74 & Tridecane \\
\hline 18.973 & 402 & $\mathrm{C}_{23} \mathrm{H}_{46} \mathrm{O}_{3} \mathrm{~S}$ & 1.66 & Sulfurous acid, cyclohexylmethylhexade \\
\hline 19.414 & 179 & $\mathrm{C}_{12} \mathrm{H}_{26}$ & 11.66 & Dodecane \\
\hline
\end{tabular}




\begin{tabular}{|c|c|c|c|c|}
\hline 19.643 & 286 & $\mathrm{C}_{16} \mathrm{H}_{30} \mathrm{O}_{4}$ & 0.16 & Oxalic acid, 6-ethyloct-3-yl isobutyl ester \\
\hline 19.719 & 184 & $\mathrm{C}_{13} \mathrm{H}_{28}$ & 0.28 & 2,4-Dimethylundecane \\
\hline 19.816 & 184 & $\mathrm{C}_{13} \mathrm{H}_{28}$ & 4.06 & 4,6-Dimethylundecane \\
\hline 19.932 & 268 & $\mathrm{C}_{19} \mathrm{H}_{40}$ & 0.54 & 5-Methyloctadecane \\
\hline 20.032 & 172 & $\mathrm{C}_{11} \mathrm{H}_{24} \mathrm{O}$ & 1.71 & 2-Isopropyl-5-methyl-1-heptanol \\
\hline 20.32 & 274 & $\mathrm{C}_{14} \mathrm{H}_{26} \mathrm{O}_{3} \mathrm{~S}$ & 0.07 & Sulfurous acid, di(cyclohexylmethyl) ester \\
\hline 20.389 & 270 & $\mathrm{C}_{18} \mathrm{H}_{38} \mathrm{O}$ & 0.14 & 2-Hexyldodecan-1-ol \\
\hline 20.484 & 238 & $\mathrm{C}_{17} \mathrm{H}_{34}$ & 1.1 & Undecylcyclohexane \\
\hline 20.777 & 184 & $\mathrm{C}_{13} \mathrm{H}_{28}$ & 0.08 & 3-Ethyl-3-methyldecane \\
\hline 21.09 & 184 & $\mathrm{C}_{13} \mathrm{H}_{28}$ & 0.35 & Dodecane, 4-methyl- \\
\hline 21.227 & 254 & $\mathrm{C}_{18} \mathrm{H}_{38}$ & 0.88 & 9-methylheptadecane \\
\hline 21.408 & 282 & $\mathrm{C}_{20} \mathrm{H}_{42}$ & 0.12 & 10-Methylnonadecane \\
\hline 21.487 & 142 & $\mathrm{C}_{10} \mathrm{H}_{22}$ & 0.25 & 2,5,5-Trimethylheptane \\
\hline 21.708 & 198 & $\mathrm{C}_{14} \mathrm{H}_{30}$ & 2.71 & 4,6-Dimethyldodecane \\
\hline 21.825 & 196 & $\mathrm{C}_{12} \mathrm{H}_{20} \mathrm{O}_{2}$ & 0.08 & 1,7,7-Trimethylbicyclo[2.2.1]hept-2-yl acetate \\
\hline 21.939 & 328 & $\mathrm{C}_{19} \mathrm{H}_{36} \mathrm{O}_{4}$ & 1.01 & Oxalic acid, 6-ethyloct-3-yl heptyl ester \\
\hline 22.098 & 212 & $\mathrm{C}_{15} \mathrm{H}_{32}$ & 0.68 & 2,6,11-Trimethyldodecane \\
\hline 22.23 & 368 & $\mathrm{C}_{23} \mathrm{H}_{44} \mathrm{O}_{3}$ & 0.51 & Carbonic acid, eicosyl vinyl ester \\
\hline 22.314 & 184 & $\mathrm{C}_{13} \mathrm{H}_{28}$ & 0.65 & 5-Butylnonane \\
\hline 22.658 & 200 & $\mathrm{C}_{13} \mathrm{H}_{28} \mathrm{O}$ & 0.97 & 11-Methyldodecanol \\
\hline 22.797 & 212 & $\mathrm{C}_{15} \mathrm{H}_{32}$ & 0.25 & 4-Methyltetradecane \\
\hline 22.881 & 200 & $\mathrm{C}_{13} \mathrm{H}_{28} \mathrm{O}$ & 0.34 & Isotridecyl alcohol \\
\hline 22.967 & 184 & $\mathrm{C}_{13} \mathrm{H}_{28}$ & 1.65 & 4-Methyldodecane \\
\hline 23.22 & 226 & $\mathrm{C}_{16} \mathrm{H}_{34}$ & 0.83 & Hexadecane \\
\hline 23.482 & 114 & $\mathrm{C}_{8} \mathrm{H}_{18}$ & 0.4 & 3,3-Dimethylhexane \\
\hline 23.625 & 286 & $\mathrm{C}_{16} \mathrm{H}_{30} \mathrm{O}_{4}$ & 13.2 & 2,2,4-Trimethyl-1,3-pentanediol diisobutyrate \\
\hline 24.357 & 204 & $\mathrm{C}_{15} \mathrm{H}_{24}$ & 0.34 & a-Copaene \\
\hline 24.488 & 190 & $\mathrm{C}_{13} \mathrm{H}_{18} \mathrm{O}$ & 0.09 & trans- $\beta$-Damascenone \\
\hline 24.72 & 218 & $\mathrm{C}_{11} \mathrm{H}_{22} \mathrm{O}_{2} \mathrm{~S}$ & 0.2 & 2-Methyl-4-pentyltetrahydro-2H-thiopyran 1,1-dioxide \\
\hline 24.959 & 198 & $\mathrm{C}_{14} \mathrm{H}_{30}$ & 0.77 & Tetradecane \\
\hline 25.159 & 204 & $\mathrm{C}_{15} \mathrm{H}_{24}$ & 0.03 & cis- $\alpha$-Bergamotene \\
\hline 25.353 & 204 & $\mathrm{C}_{15} \mathrm{H}_{24}$ & 0.79 & Guaia-6,9-diene \\
\hline 25.652 & 204 & $\mathrm{C}_{15} \mathrm{H}_{24}$ & 0.44 & Caryophyllene \\
\hline 26.124 & 204 & $\mathrm{C}_{15} \mathrm{H}_{24}$ & 0.5 & trans- $\alpha$-Bergamotene \\
\hline 26.552 & 194 & $\mathrm{C}_{13} \mathrm{H}_{22} \mathrm{O}$ & 0.07 & 6,10-Dimethyl-undeca-5,9-dien-2-one \\
\hline 26.765 & 204 & $\mathrm{C}_{15} \mathrm{H}_{24}$ & 0.08 & $\beta$-Farnesene \\
\hline 27.45 & 204 & $\mathrm{C}_{15} \mathrm{H}_{24}$ & 0.17 & Guaia-1(10),11-diene \\
\hline 27.764 & 202 & $\mathrm{C}_{12} \mathrm{H}_{22}$ & 0.52 & a-Curcumene \\
\hline 28.187 & 220 & $\mathrm{C}_{15} \mathrm{H}_{24} \mathrm{O}$ & 0.06 & 6-Epishyobunone \\
\hline 28.366 & 268 & $\mathrm{C}_{19} \mathrm{H}_{40}$ & 0.18 & Norphytane \\
\hline
\end{tabular}




\begin{tabular}{|c|c|c|c|c|}
\hline 28.486 & 212 & $\mathrm{C}_{15} \mathrm{H}_{32}$ & 0.18 & Pentadecane \\
\hline 29.23 & 192 & $\mathrm{C}_{11} \mathrm{H}_{12} \mathrm{O}_{3}$ & 0.05 & Myristicin \\
\hline 29.819 & 204 & $\mathrm{C}_{15} \mathrm{H}_{24}$ & 0.02 & $\begin{array}{l}\text { Naphthalene, 1,2,3,4,4a,7-hexahydro-1,6-dimethyl-4-(1- } \\
\text { methylethyl)- }\end{array}$ \\
\hline 30.17 & 282 & $\mathrm{C}_{20} \mathrm{H}_{42}$ & 0.09 & Eicosane \\
\hline 30.686 & 200 & $\mathrm{C}_{12} \mathrm{H}_{24} \mathrm{O}_{2}$ & 0.04 & Dodecanoic acid \\
\hline 31.248 & 220 & $\mathrm{C}_{15} \mathrm{H}_{24} \mathrm{O}$ & 0.17 & (-)-Spathulenol \\
\hline 31.674 & 312 & $\mathrm{C}_{20} \mathrm{H}_{40} \mathrm{O}_{2}$ & 0.04 & Octadecanoic acid, ethyl ester \\
\hline 31.778 & 286 & $\mathrm{C}_{16} \mathrm{H}_{30} \mathrm{O}_{4}$ & 0.58 & 2,2,4-Trimethyl-1,3-pentanediol diisobutyrate \\
\hline 31.868 & 240 & $\mathrm{C}_{17} \mathrm{H}_{36}$ & 0.18 & Heptadecane \\
\hline 34.091 & 226 & $\mathrm{C}_{16} \mathrm{H}_{34}$ & 0.04 & 2,6,10-Trimethyltridecane \\
\hline 34.991 & 218 & $\mathrm{C}_{15} \mathrm{H}_{22} \mathrm{O}$ & 0.1 & $\begin{array}{l}\text { 2H-Cyclopropa[a]naphthalen-2-one, 1,1a,4,5,6,7,7a,7b-octahydro- } \\
\text { 1,1,7,7a-tetramethyl-, (1a.alpha.,7.alpha.,7a.alpha.,7b.alpha.)- }\end{array}$ \\
\hline 35.471 & 256 & $\mathrm{C}_{16} \mathrm{H}_{32} \mathrm{O}_{2}$ & 0.02 & Ethyl myristate \\
\hline 35.575 & 240 & $\mathrm{C}_{17} \mathrm{H}_{36}$ & 0.02 & Heptadecane \\
\hline 36.189 & 268 & $\mathrm{C}_{18} \mathrm{H}_{36} \mathrm{O}$ & 0.12 & 2-Pentadecanone, 6,10,14-trimethyl- \\
\hline 36.476 & 278 & $\mathrm{C}_{16} \mathrm{H}_{22} \mathrm{O}_{4}$ & 0.27 & 1-Butyl 2-isobutyl phthalate \\
\hline 37.196 & 270 & $\mathrm{C}_{17} \mathrm{H}_{34} \mathrm{O}_{2}$ & 0.09 & Hexadecanoic acid, methyl ester \\
\hline 37.564 & 256 & $\mathrm{C}_{16} \mathrm{H}_{32} \mathrm{O}_{2}$ & 0.01 & n-Hexadecanoic acid \\
\hline 37.623 & 278 & $\mathrm{C}_{16} \mathrm{H}_{22} \mathrm{O}_{4}$ & 0.02 & Dibutyl phthalate \\
\hline 37.978 & 284 & $\mathrm{C}_{18} \mathrm{H}_{36} \mathrm{O}_{2}$ & 0.17 & Hexadecanoic acid, ethyl ester \\
\hline
\end{tabular}

The $\%$ area is expressed as a $\%$ of the total area under all chromatographic peaks.

diluted in artificial seawater for use in the Artemia franciscana nauplii bioassay.

\section{Artemia franciscana nauplii toxicity screening}

Toxicity was tested using a modified $A$. franciscana nauplii lethality assay. ${ }^{32-34}$ Briefly, $400 \mu \mathrm{L}$ of seawater containing approximately 44 (mean 43.8, $\mathrm{n}=120, \mathrm{SD} 12.1$ ) A. franciscana nauplii were added to wells of a 48 well plate and immediately used for bioassay. A volume of $400 \mu \mathrm{L}$ of diluted plant extracts or the reference toxin were transferred to the wells and incubated at $25 \pm 1^{\circ} \mathrm{C}$ under artificial light (1000 Lux). A negative control $(400 \mu \mathrm{L}$ seawater) was run in triplicate for each plate. All treatments were performed in at least triplicate. The wells were checked at regular intervals and the number of dead counted. The nauplii were considered dead if no movement of the appendages was observed within $10 \mathrm{sec}$. After $24 \mathrm{~h}$, all A. franciscana nauplii were sacrificed and counted to determine the total $\%$ mortality per well. The $\mathrm{LC}_{50}$ with $95 \%$ confidence limits for each treatment was calculated using probity analysis.

\section{Non-targeted GC-MS head space analysis}

Separation and quantification were performed using a Shimadzu GC2010 plus (USA) linked to a Shimadzu MS TQ8040 (USA) mass selective detector system as previously described. ${ }^{35,36}$ The system was equipped with a Shimadzu auto-sampler AOC-5000 plus (USA) fitted with a solid phase micro-extraction fibre (SPME) handling system utilising a Supelco (USA) divinely benzene/carbowax/polydimethylsiloxane (DVB/CAR/ PDMS). Chromatographic separation was accomplished using a $5 \%$ phenyl, $95 \%$ dimethylpolysiloxane $(30 \mathrm{~m} \times 0.25 \mathrm{~mm}$ id $\times 0.25 \mathrm{um}$ ) capillary column (Restek USA). Helium (99.999\%) was employed as a carrier gas at a flow rate of $0.79 \mathrm{~mL} / \mathrm{min}$. The injector temperature was set at $230^{\circ} \mathrm{C}$. Sampling utilised a SPME cycle which consisted of an agitation phase at $500 \mathrm{rpm}$ for a period of $5 \mathrm{sec}$. The fibre was exposed to the sample for $10 \mathrm{~min}$ to allow for absorption and then desorbed in the injection port for $1 \mathrm{~min}$ at $250^{\circ} \mathrm{C}$. The initial column temperature was held at $30^{\circ} \mathrm{C}$ for $2 \mathrm{~min}$, increased to $140^{\circ} \mathrm{C}$ for $5 \mathrm{~min}$, then increased to $270^{\circ} \mathrm{C}$ over a period of 3 mins and held at that temperature for the duration of the analysis. The GC-MS interface was maintained at $200^{\circ} \mathrm{C}$ with no signal acquired for a min after injection in split-less mode. The mass spectrometer was operated in the electron ionisation mode at $70 \mathrm{eV}$. The analytes were then recorded in total ion count (TIC) mode. The TIC was acquired after a $\mathrm{min}$ and fora duration of 45 mins utilising a mass range of $45-450 \mathrm{~m} / \mathrm{z}$.

\section{Statistical analysis}

Data are expressed as the mean \pm SEM of at least three independent experiments. One way ANOVA was used to calculate statistical significance between control and treated groups with a $P$ value $<0.01$ considered to be statistically significant. 


\section{RESULTS}

\section{Extraction yields and qualitative phytochemical screening}

Extraction of $1 \mathrm{~kg}$ of air-dried aerial parts of C. maritima-with $5 \mathrm{~L}$ of $70 \%$ methanol yielded $58 \mathrm{~g}$ ( $5.8 \%$ yield) of dark black extract. Sequential extraction of the total extract with $n$-hexane, ethyl acetate and methanol yielded $10.5 \mathrm{~g}$ (approximately 1.1\% yield), $15.0 \mathrm{~g}$ (approximately 1.5\% yield) and $32.5 \mathrm{~g}$ (approximately 3.3\% yield) of the total extracted material, respectively. The dried extracts were resuspended in deionised water (containing 1\% DMSO) to give the extract concentrations shown in Table 2.

Qualitative phytochemical studies showed that all extracts contained a similar range of phytochemical classes (Table 2). Phenolics (both water soluble and insoluble phenolics) and flavonoids were present in moderatehigh levels in the ethyl acetate and methanolic extracts. Whilst triterpenoids were also present in all extracts, they were present in only low abundance. Saponins were only present in methanolic and ethyl acetate extracts, while phytosterols were present in methanolic and hexane extracts in low relative abundance. Alkaloids were only present in the methanolic extract, and then only in low relative abundance. All extracts were completely devoid of cardiac glycosides, tannins and anthraquinones.

\section{Antioxidant content}

Antioxidant capacity (expressed as the concentration capable of scavenging $50 \%$ of the DPPH radical) for the C. maritima extracts (Table 2) ranged from a DPPH radical scavenging $\mathrm{IC}_{50}$ of $3.4 \mu \mathrm{g} / \mathrm{mL}$ (ethyl acetate C. maritime extract) to a high of $13.6 \mu \mathrm{g} / \mathrm{mL}$ (C. maritima hexane extract).

\section{Antimicrobial activity}

To determine the antimicrobial activity of the crude plant extracts, aliquots $(10 \mu \mathrm{L})$ of each extract were tested in the disc diffusion assay against a panel of bacteria previously identified as microbial triggers of autoimmune inflammatory diseases. Proteus mirabilis growth was inhibited by all of the C. maritima extracts (Figure 1). The methanolic extract was a particularly good $P$. mirabilis growth inhibitor, with a $12 \mathrm{~mm}$ zone of inhibition (compared to $14 \mathrm{~mm}$ for the ampicillin control). Whilst inducing a substantially smaller zone of inhibition $(9.3 \mathrm{~mm})$, the ethyl acetate extract is still considered to be a strong $P$. mirabilis growth inhibitor. The hexane extract also inhibited $P$. mirabilis growth, albeit with zone of inhibition $(7.3 \mathrm{~mm})$ which indicates low-moderate inhibition.

The growth of $P$. vulgaris was substantially more susceptible to inhibition by the C. maritima extracts than was $P$. mirabilis (as judged by the zones of inhibition). Interestingly, the nonpolar hexane extracts appeared to be a much more potent bacterial growth inhibitor than the more polar methanolic and ethyl acetate extracts (Figure 2). Indeed, a $20 \mathrm{~mm}$ zone of inhibition was measured for P. vulgaris growth. This is particularly noteworthy when compared to the inhibition of the ampicillin control antibiotic $(10.3 \mathrm{~mm})$, and when compared to the inhibition by the same extract of $P$. mirabilis growth $(7.3 \mathrm{~mm}$; Figure 1$)$. The methanolic and ethyl acetate extracts were also potent $P$. vulgaris growth inhibitors (all with zones of inhibition $>12 \mathrm{~mm}$ ).

All C. maritima extracts also inhibited K. pneumonia growth (Figure 3), albeit with substantially smaller zones of inhibition compared to the growth inhibition of the Proteus spp. Inhibition zones substantially $<7.5 \mathrm{~mm}$ in diameter were recorded for all extracts, indicating low K. pneumoniae growth inhibitory efficacy. Similarly, the C. maritima extracts were poor inhibitors of $A$. baylyi growth. Indeed, the methanolic and ethyl acetate extracts were completely devoid of $A$. baylyi inhibitory activity (Figure 4). Furthermore, the small $A$. baylyi inhibition zone $(7.3 \pm 0.3 \mathrm{~mm})$ recorded for the C. maritima hexane extract is indicative of only low antibacterial potency.

In contrast, potent $P$. aeruginosa growth inhibition was noted for the $C$. maritima ethyl acetate extract (zone of inhibition $=9.3 \pm 0.6 \mathrm{~mm}$; Figure 5 ). This is a particularly significant result as the ampicillin control only inhibited $P$. aeruginosa growth with low efficacy, indicating that the $P$. aeruginosa strain tested in our study was ampicillin resistant. Indeed, previous studies from our group have also shown the low susceptibility of these $P$. aeruginosa strains to conventional antibiotics. ${ }^{35,36}$ The methanolic and ethyl acetate extracts also inhibited $P$. aeruginosa growth, albeit with substantially smaller zones of inhibition $(6.0 \pm 0$ and $6.7 \pm 0.3 \mathrm{~mm}$, respectively).

The antimicrobial efficacy was further quantified by determining the MIC values for each extract against the microbial species which were determined to be susceptible. Many of the extracts were effective at inhibiting microbial growth (Table 3), with MIC values against several of the susceptible bacteria substantially $<1000 \mu \mathrm{g} / \mathrm{mL}(<10 \mu \mathrm{g}$ infused into the disc), indicating the potential of these extracts in controlling multiple autoimmune inflammatory disorders. The MIC values determined for the ethyl acetate and hexane extracts were particularly noteworthy, especially against the microbial triggers of rheumatoid arthritis (P. mirabilis and P. vulgaris) with MIC values generally $400-800 \mu \mathrm{g} / \mathrm{mL}$ (4-8 $\mu \mathrm{g}$ impregnated in the disc). The ethyl acetate was also a potent inhibitor of $P$. aeruginosa $(\mathrm{MIC}=777 \mu \mathrm{g} / \mathrm{mL})$. As $P$. aeruginosa is one of the bacterial triggers of multiple sclerosis, the C. maritima extract also has potential in the prevention and treatment of that disease. Similarly, MIC values of $777 \mu \mathrm{g} / \mathrm{mL}$ and $1625 \mu \mathrm{g} / \mathrm{mL} \mu \mathrm{g} / \mathrm{mL}$ were determined for the ethyl acetate $C$. maritima extract against the other trigger of multiple sclerosis (A. baylyi) and a microbial trigger of ankylosing spondylitis (Klebsiella pneumoniae). These MIC values are indicative of moderate growth inhibitory activity. Therefore, these extracts also have potential in the treatment of these diseases.

\section{Quantification of toxicity}

All extracts were initially screened undiluted in the assay (Figure 6). For comparison, the reference toxin potassium dichromate $(1000 \mu \mathrm{g} / \mathrm{mL})$ was also tested in the bioassay. The potassium dichromate reference toxin was rapid in its onset of mortality, inducing nauplii death within the first $3 \mathrm{~h}$ of exposure and $100 \%$ mortality was evident following $4-5 \mathrm{~h}$ (results not shown). In contrast, the methanolic and hexane C. maritima extracts did not induce mortality rates significantly different from those of the untreated seawater control. Only the ethyl acetate extract induced $>50 \%$ mortality rates at $24 \mathrm{~h}$. Therefore, the methanolic and hexane C. maritima extracts were deemed non-toxic whilst the ethyl acetate extract was deemed toxic (based on the screening study mortality). The toxicity of the ethyl acetate extract was therefore further evaluated.

To further quantify the effect of toxin concentration on the induction of mortality, the extracts were serially diluted in artificial seawater to test across a range of concentrations in the Artemia nauplii bioassay. Table 3 shows the $\mathrm{LC}_{50}$ values of C. maritima extracts towards $A$. franciscana. No $\mathrm{LC}_{50}$ values are reported for the methanolic and hexane extracts as $<50 \%$ mortality was seen for all concentrations tested. In contrast, an $\mathrm{LC}_{50}$ value of $1361 \mu \mathrm{g} / \mathrm{mL}$ was determined for the $C$. maritima ethyl acetate extract following $24 \mathrm{~h}$ exposure. Extracts with an $\mathrm{LC}_{50}$ values $>1000 \mu \mathrm{g} / \mathrm{mL}$ towards Artemia nauplii have been defined as being nontoxic. ${ }^{34}$ Thus, the C. maritima ethyl acetate extract was also deemed to be nontoxic.

\section{Non-targeted GC-MS headspace analysis}

As the ethyl acetate C. maritima extract had the most potent growth inhibitory efficacy against most bacterial species (as determined by MIC; Table 2), it was deemed the most promising extract for further 


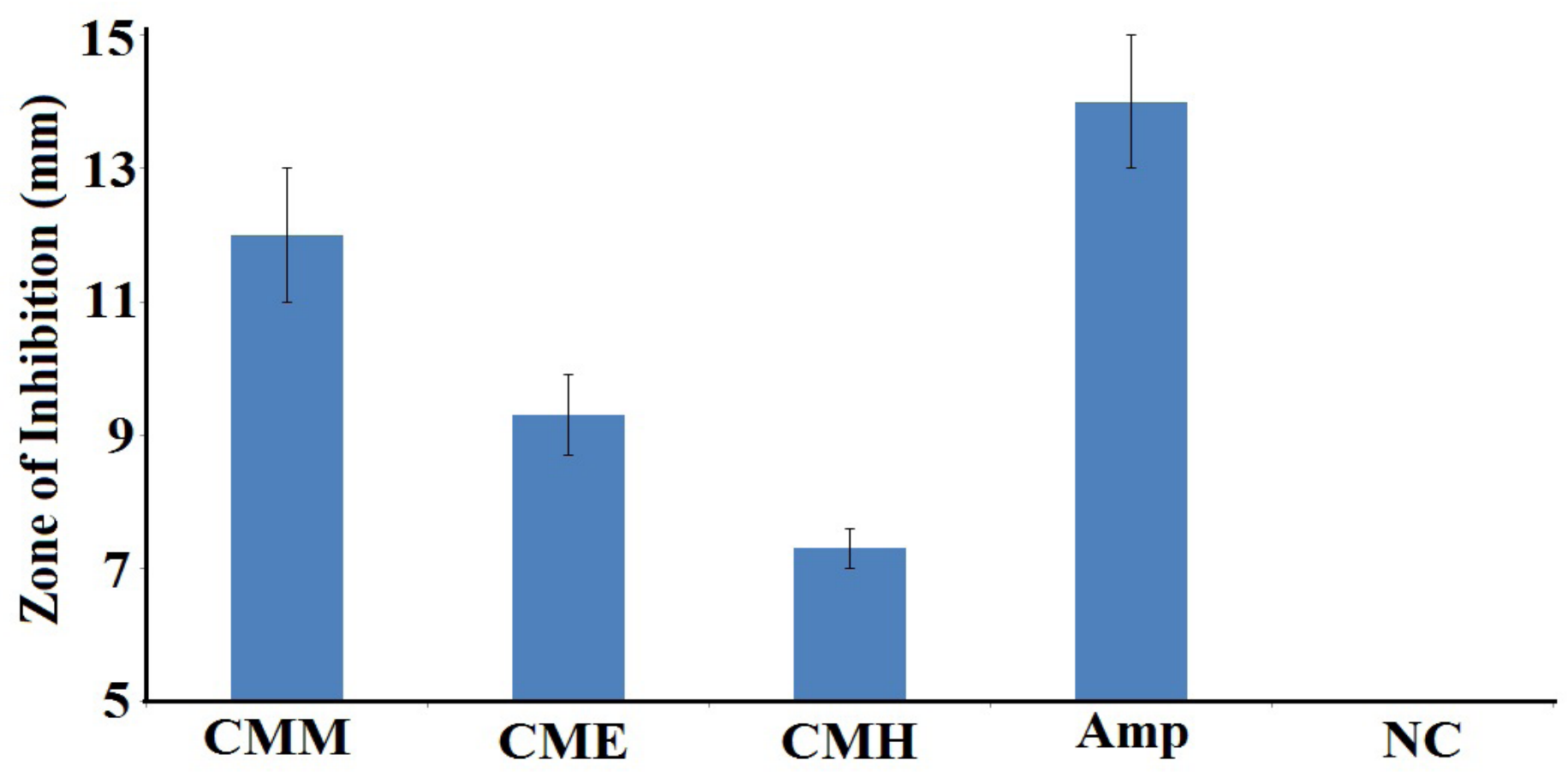

Figure 1: Antibacterial activity of the C. maritime extracts against a $P$. mirabilis reference strain (ATCC:21721) measured as zones of inhibition (mm). CMM $=C$. maritime methanolic extract; $\mathrm{CME}=C$. maritime ethyl acetate extract; $\mathrm{CMH}=C$. maritime hexane extract; $\mathrm{Amp}=\mathrm{ampicillin}(10 \mu \mathrm{gg})$ control; $\mathrm{NC}=0.5 \% \mathrm{DMSO}$. Results are expressed as mean zones of inhibition \pm SEM.

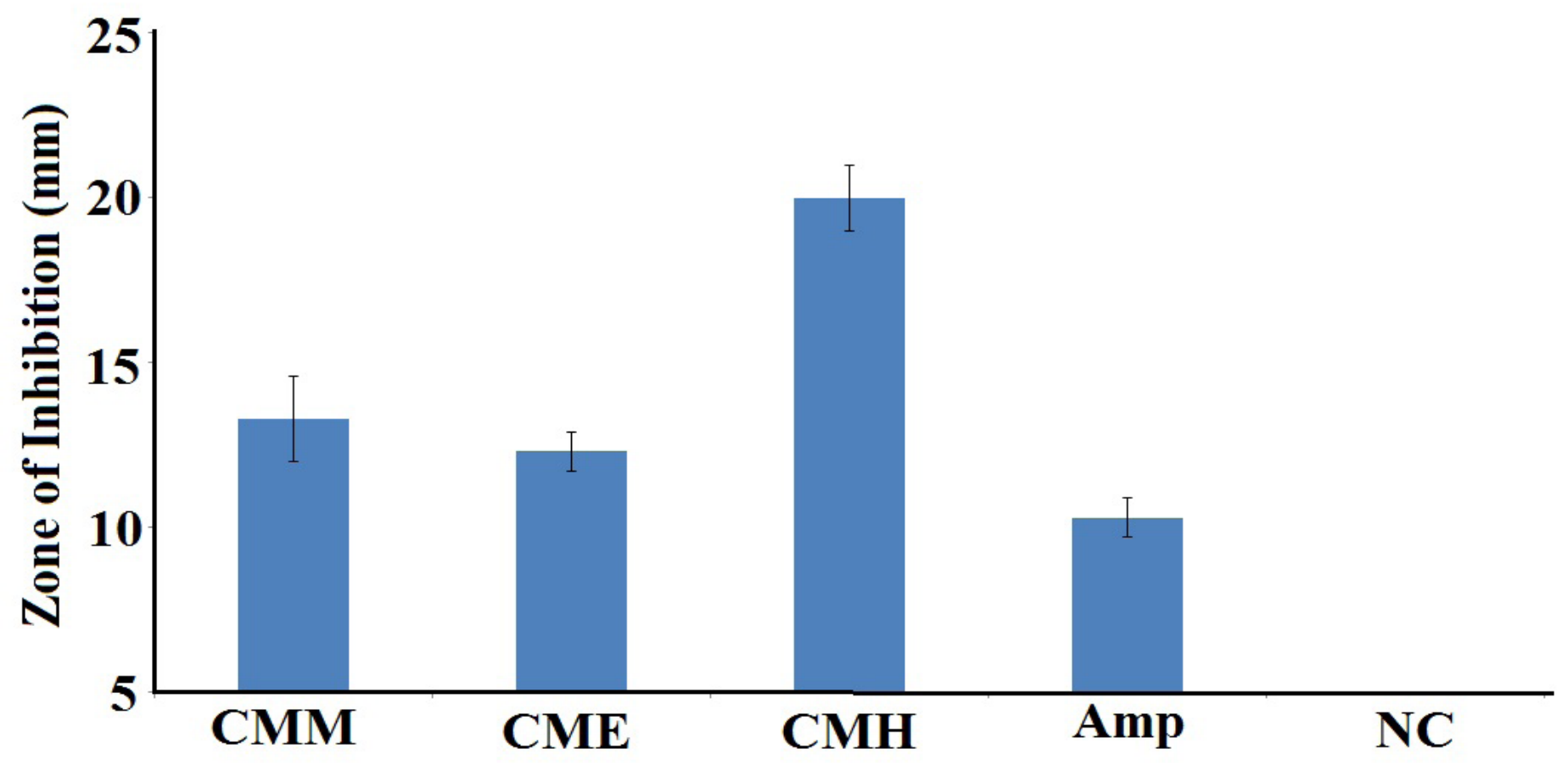

Figure 2: Antibacterial activity of $C$. maritime extracts against $P$. vulgaris (ATCC21719) measured as zones of inhibition (mm). CMM=C. maritime methanolic extract; $\mathrm{CME}=C$. maritime ethyl acetate extract; $\mathrm{CMH}=C$. maritime hexane extract; $\mathrm{Amp}=$ ampicillin $(10 \mu \mathrm{g})$ control; $\mathrm{NC}=0.5 \% \mathrm{DMSO}$. Results are expressed as mean zones of inhibition \pm SEM. 


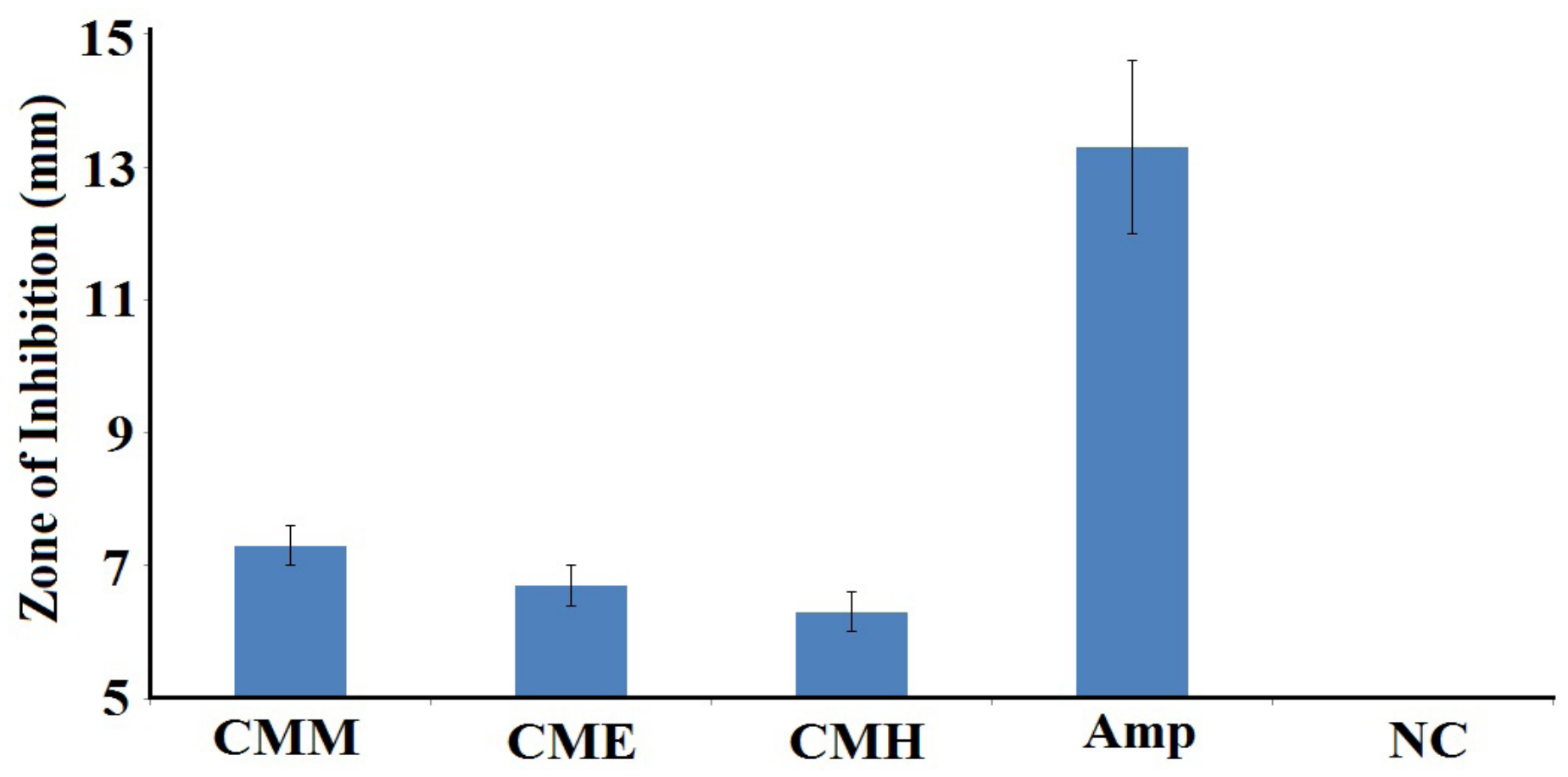

Figure 3: Antibacterial activity of the C. maritime extracts against a $K$. pneumonia reference strain (ATCC31488) measured as zones of inhibition (mm). CMM=C. maritime methanolic extract; $\mathrm{CME}=\mathrm{C}$. maritime ethyl acetate extract; $\mathrm{CMH}=\mathrm{C}$. maritime hexane extract; $\mathrm{Amp}=\mathrm{ampicillin}(10 \mu \mathrm{g}) \mathrm{control} ; \mathrm{NC}=0.5 \% \mathrm{DMSO}$. Results are expressed as mean zones of inhibition \pm SEM.

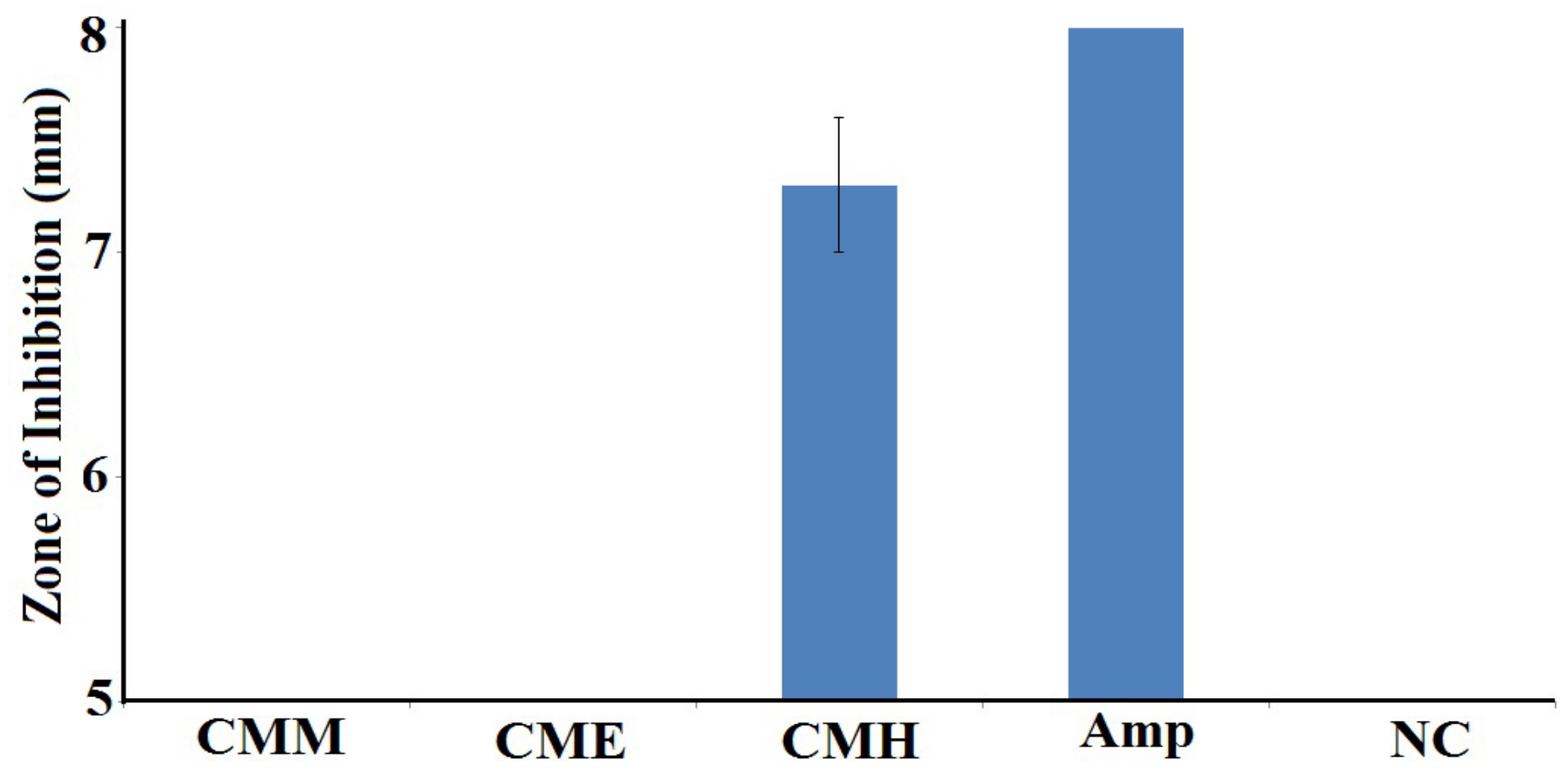

Figure 4: Antibacterial activity of the C. maritime extracts againsta A. baylyi reference strain (ATCC31488) measured as zones of inhibition (mm). CMM=C. maritime methanolic extract; $\mathrm{CME}=\mathrm{C}$. maritime ethyl acetate extract; $\mathrm{CMH}=\mathrm{C}$. maritime hexane extract; $\mathrm{Amp}=\mathrm{ampicillin}(10 \mu \mathrm{gg}) \mathrm{Control}$; $\mathrm{NC}=0.5 \% \mathrm{DMSO}$. Results are expressed as mean zones of inhibition \pm SEM. 


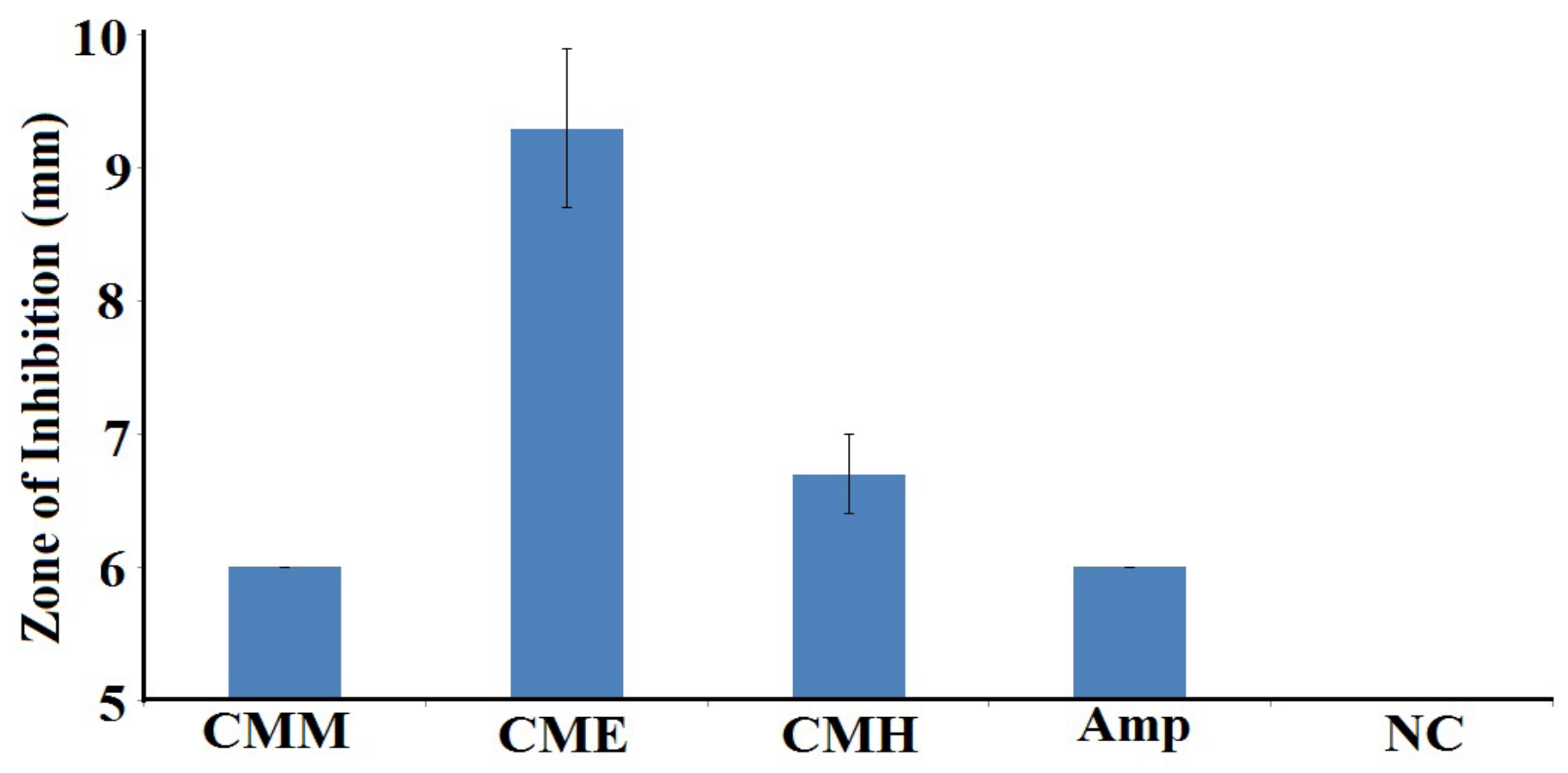

Figure 5: Antibacterial activity of the $C$. maritime extracts against a $P$. aeruginosa reference strain (ATCC31488) measured as zones of inhibition (mm). $C M M=C$. maritime methanolic extract; $\mathrm{CME}=C$. maritime ethyl acetate extract; $\mathrm{CMH}=\mathrm{C}$. maritime hexane extract; $\mathrm{Amp}=$ ampicillin $(10 \mu \mathrm{gg}) \mathrm{control}$; $\mathrm{NC}=0.5 \% \mathrm{DMSO}$. Results are expressed as mean zones of inhibition \pm SEM.

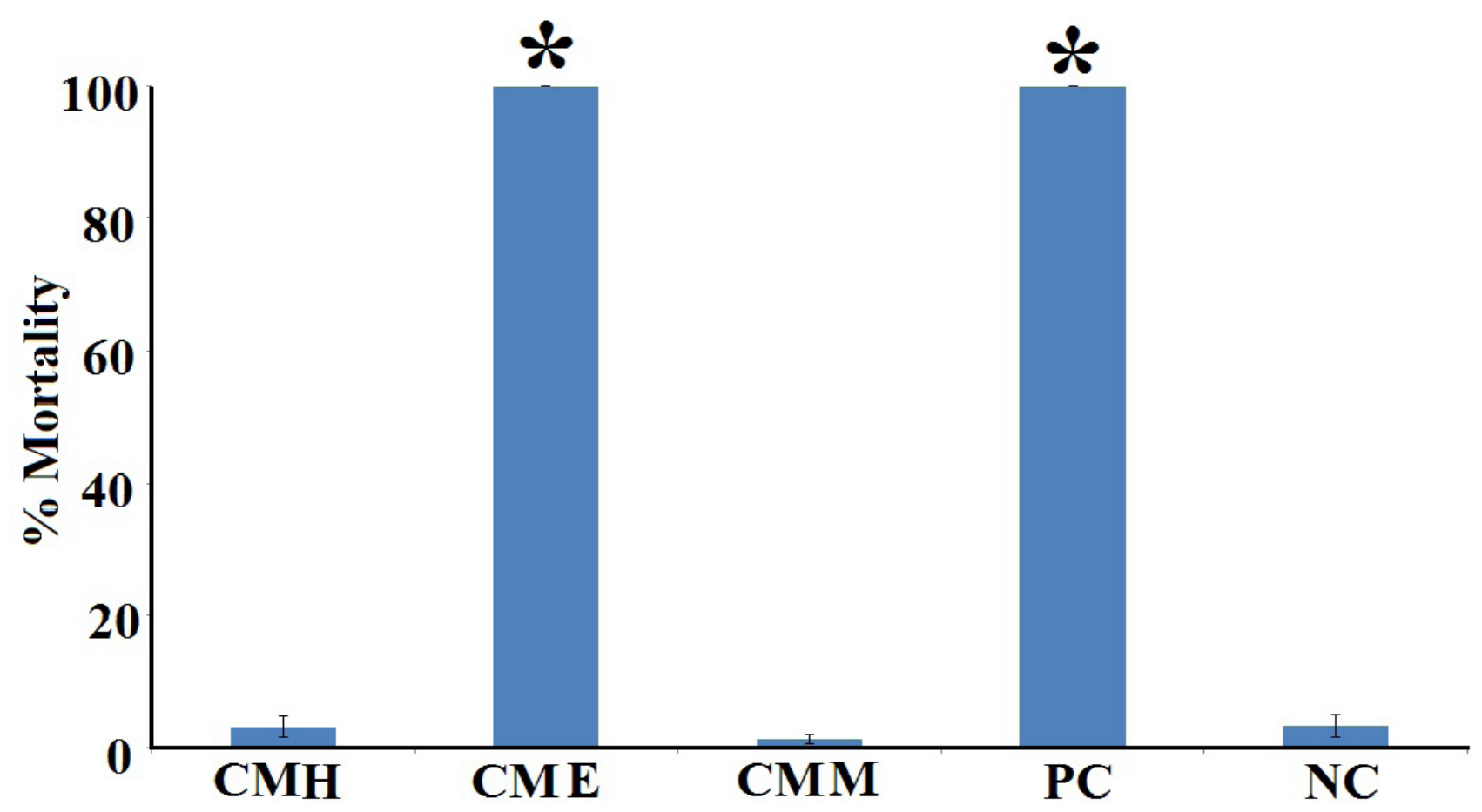

Figure 6: The lethality of the C. maritima extracts $(2000 \mu \mathrm{g} / \mathrm{mL})$ and the potassium $(1000 \mu \mathrm{g} / \mathrm{mL})$ towards Artemia nauplii following $24 \mathrm{~h}$ exposure. CMM=C. maritima methanolic extract; $\mathrm{CME}=C$. maritima ethyl acetate extract; $\mathrm{CMH}=\mathrm{C}$. maritima hexane extract; $\mathrm{PC}=$ positive control $(1000 \mu \mathrm{g} / \mathrm{mL}$ potassium dichromate); $\mathrm{NC}=$ negative (seawater) control. All tests were performed in at least triplicate and the results are expressed as mean \pm SEM.* indicates results that are significantly different to the negative seawater control $(p<0.01)$. 


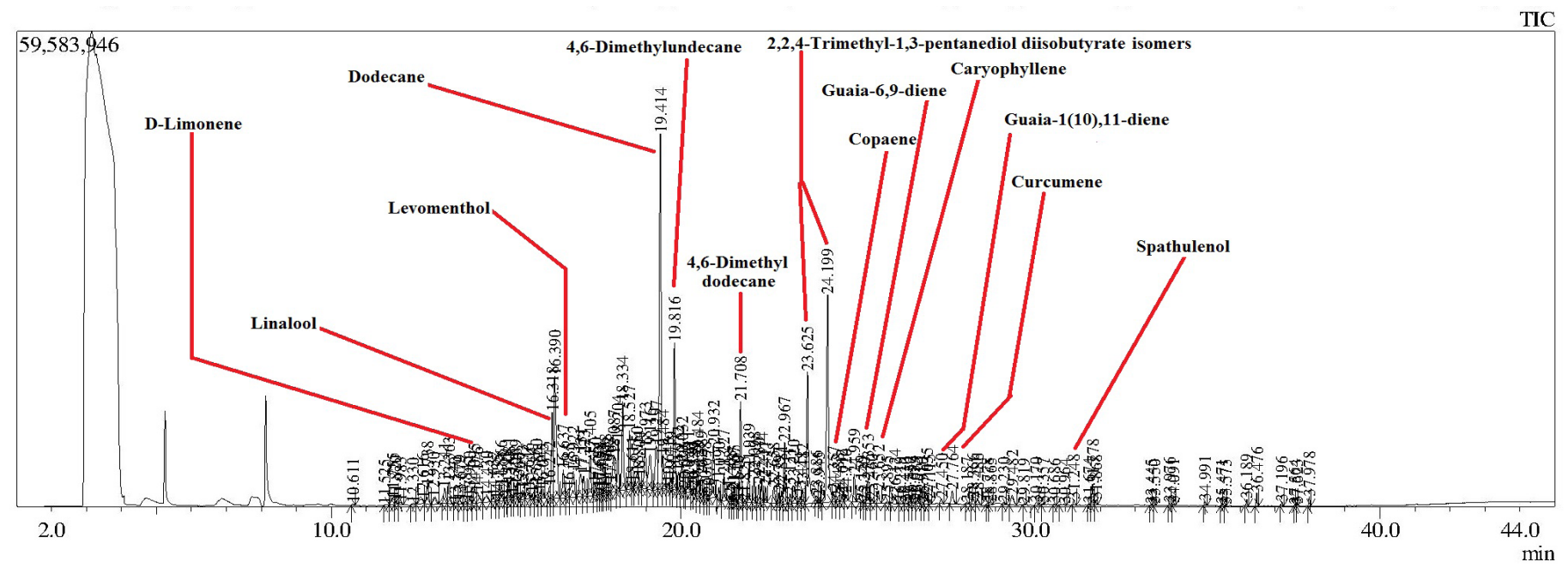

Figure 7: GC headspace total ion chromatogram of $0.5 \mu \mathrm{L}$ injection of $C$. maritima ethyl acetate extract. The extract was dried and resuspended in methanol for analysis. Some of the major components (by relative \% prevalence) are indicated on the chromatogram.
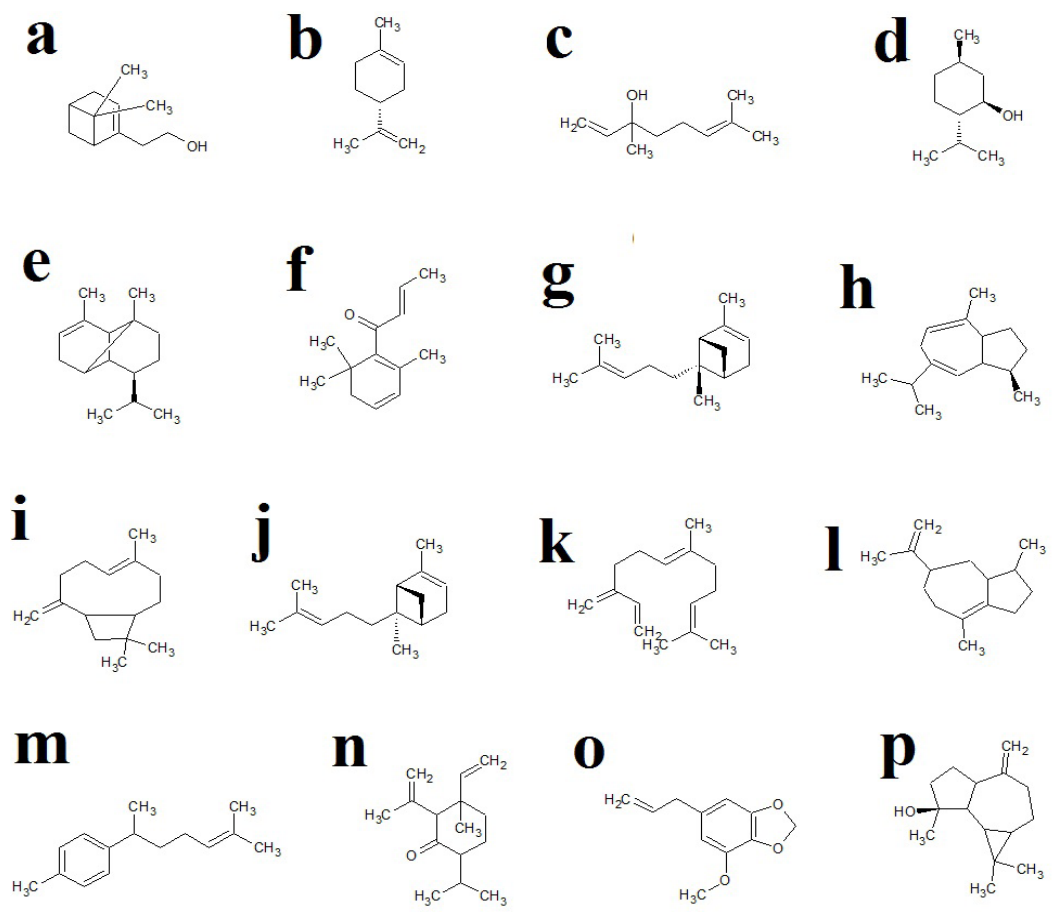

Figure 8: Terpenoids and other major phytochemical compounds detected in the ethyl acetate C. maritima extract: (a) homomyrtenol; (b) D-limonene; (c) linalool; (d) levomenthol; (e) a-copaene; (f) trans- $\beta$-damascenone; (g) cis-a-bergamotene; (h) guaia-6,9-diene; (i) caryophyllene; (j) trans-a-bergamotene; (k) $\beta$-farnesene; (I) guaia-1(10),11-diene; (m) a-curcumene; (n) 6-epishyobunone; (o) myristicin; (p) spathulenol.

phytochemical analysis. Optimised GC-MS parameters were developed and used to examine the phytochemical composition of these extracts. The resultant gas chromatogramis presented in Figure 7. Major peaks were evident at approximately 16.3, 16.4, 19.4, 19.8, 21.7, 23.6 and 24.2 min (Figure 7). Several smaller peaks were also evident throughout all stages of the chromatogram. In total, 97 unique mass signals were noted for the C. maritima ethyl acetate extract (Table 4). Putative empirical formulas and identifications were achieved for all of these compounds by comparison with a commercial database.
The major compounds present (as determined by relative \% area under each peak) were the hydrocarbons dodecane (19.4 min; $11.7 \%$ relative abundance) and 4,6-dimethylundecane ( $19.8 \mathrm{~min}$; $4.1 \%$ relative abundance). However, a number of other interesting compounds including D-limonene (14.1 min; 0.7\% relative abundance), linalool (16.3 min; $2.7 \%$ relative abundance), levomenthol ( $16.6 \mathrm{~min} ; 1.0 \%$ relative abundance), 4,6-dimethyldodecane (21.7 $\mathrm{min} ; 2.7 \%$ relative abundance), 2,2,4-Trimethyl-1,3-pentanediol diisobutyrate isomers (23.6 and 24.1 $\mathrm{min} ; 13.2 \%$ total relative abundance), $\alpha$-copaene $(24.4 \mathrm{~min}$; $0.3 \%$ rela- 
tive abundance), guaia-6,9-diene (25.4 $\mathrm{min} ; 0.8 \%$ relative abundance), caryophyllene (25.7 $\mathrm{min} ; 0.4 \%$ relative abundance), guaia-1(10),11diene (27.5 $\mathrm{min} ; 0.2 \%$ relative abundance), $\alpha$-curcumene ( $27.8 \mathrm{~min} ; 0.5 \%$ relative abundance) and spathulenol ( $31.2 \mathrm{~min} ; 0.2 \%$ relative abundance) were present in significant levels. Three sulphur containing compounds were detected in the ethyl acetate extract; sulfurous acid, cyclohexylmethyl hexade (18.973 min, 1.66\% relative abundance), sulfurous acid, di(cyclohexylmethyl) ester (20.32 $\mathrm{min}, 0.07 \%$ relative abundance) and 2-methyl-4-pentyltetrahydro-2H-thiopyran 1,1-dioxide $(24.72 \mathrm{~min}$, $0.2 \%$ relative abundance).

\section{DISCUSSION}

Plant remedies are becoming increasingly sought after in the treatment of a myriad of diseases and disorders due both to their perception of greater safety than synthetic drugs, and the failure of current drug regimens to effectively treat many diseases. This is especially true for the autoimmune inflammatory diseases. The current treatments utilising disease modifying anti-rheumatic drugs (DMARDs) to alleviate the symptoms of these diseases and/or alter the disease progression are not entirely effective and have been associated with numerous adverse effects. ${ }^{10}$ Furthermore, many of the current treatments are aimed at treating the symptoms without addressing the underlying causes and pathogenic mechanisms. Therefore, whilst these treatments may alleviate pain, redness, swelling etc., they do not address the tissue degeneration which occurs as a consequence of the disease etiology. Furthermore, all of these drugs are used as treatments and there are currently no preventative therapy options. A better understanding of the mechanisms for initiation and progression of the autoimmune inflammatory diseases is important for developing new drugs to target specific processes and thus more effectively treat autoimmune inflammatory diseases.

The studies reported here examined the ability of $C$. maritima extracts to block microbial triggers of 3 autoimmune inflammatory disorders (Proteus spp.: rheumatoid arthritis; K. pneumonia: ankylosing spondylitis; A. baylyi and P. aeruginosa: multiple sclerosis). The ethyl acetate extract was identified as displaying the most potent growth inhibition against these bacteria. It was a particularly good inhibitor of Proteus spp. growth, with MIC values of 431 and $559 \mu \mathrm{g} / \mathrm{mL}$ against $P$. mirabilis and $P$. vulgaris, respectively. As Proteus spp. have been shown to induce rheumatoid arthritis in genetically susceptible individuals, the C. maritima ethyl acetate extract has potential for the development of rheumatoid arthritis inhibitory therapies. As this is a crude extract containing a number of known bioactive components, it is possible that it may function similarly to combinational therapies ${ }^{37}$ and may also affect other phases of the rheumatoid arthritis disease process (e.g. regulation of cytokine production, immunomodulation etc.) and thus may have pleuripotent effects. Further studies are required to test the effect of the extract on these other phases of the disease progression. If other therapeutic effects are subsequently detected, C. maritima ethyl acetate extract may be a particularly attractive option for chronic sufferers of this disease, to block its onset as well as treating its symptoms once it is initiated.

The C. maritima ethyl acetate extract also had moderate K. pneumoniae growth inhibitory properties (MIC value $=1625 \mu \mathrm{g} / \mathrm{mL}$ ), indicating that it may also be useful in the prevention of ankylosing spondylitis. Whilst ankylosing spondylitis affects different tissue than rheumatoid arthritis, it has a similar multiple phased progression. The ethyl acetate extract may therefore also have further effects on other phases of ankylosing spondylitis disease. Indeed, it is possible that the extract may also modulate cytokine production and therefore also block later inflammatory disease events, although this has yet to be tested for our extracts.
Similarly, the C. maritima ethyl acetate extract also was a good inhibitor of $P$. aeruginosa growth, with an MIC value of $777 \mu \mathrm{g} / \mathrm{mL}$ and thus may be useful in the prevention and treatment of multiple sclerosis. However, it is unlikely that $C$. maritima ethyl acetate would be completely effective as a preventative therapy as $A$. baylyi is a further trigger of multiple sclerosis and this extract was completely devoid of growth inhibitory activity against these bacteria. Thus it is likely that the disease could still be triggered if susceptible individuals were exposed to this bacterium, even when treated with $C$. maritima ethyl acetate extract. However, the therapeutic properties of the extract in the treatment of autoimmune diseases may be of greater efficacy as synergistic actions may exist between various therapeutic mechanisms (antibacterial, anti-inflammatory, antioxidant, immune-stimulatory etc.), providing combined effects on these complex diseases. Of further note, the antibacterial and MIC assays performed in our study utilised agar based methods. Whilst these are effective in many cases, they often under estimate the efficacy of very low polarity mixtures such as essential oils as the low polarity compounds do not diffuse well within the agar gels. Furthermore, volatile compounds in essential oils are often lost due to evaporation, resulting in falsely low efficacies. Whilst our study tested extracts rather than oils, GC-MS analysis of the ethyl acetate extract detected a number of low polarity volatile terpenoids. Thus, perhaps testing by liquid dilution MIC techniques may have yielded lower MIC values, indicative of greater efficacy and further studies are required to test this.

The bacterial growth inhibitory activity of the C. maritima extracts generally correlated with their antioxidant capacities (as measured as free radical scavenging activities). The ethyl acetate extract had the lowest free radical scavenging $\mathrm{IC}_{50}$ value $(3.4 \mu \mathrm{g} / \mathrm{mL})$ of the C. maritima extracts. In comparison, free radical scavenging $\mathrm{IC}_{50}$ values of 4.7 and $13.6 \mu \mathrm{g} / \mathrm{mL}$ were determined for methanolic and hexane extracts, respectively. Thus, substantially less $C$. maritima ethyl acetate extract is required to scavenge $\mathrm{DPPH}$ radical than for the methanolic and hexane extracts.

GC-MS headspace analysis of the C. maritima ethyl acetate extract detected a number of interesting compounds, including a wide diversity of terpenoids. Sesquiterpenoids were particularly prevalent, with 10 sesquiterpenoids including $\alpha$-copaene (Figure 8e), cis- $\alpha$-bergamotene (Figure 8g), guaia-6,9-diene (Figure 8h), caryophyllene (Figure 8i), trans- $\alpha$-bergamotene (Figure $8 \mathrm{i}$ ), $\beta$-farnesene (Figure 8k), guaia-1(10), 11-diene (Figure 81), $\alpha$-curcumene (Figure $8 \mathrm{~m}$ ), 6-epishyobunone (Figure $8 \mathrm{n}$ ) and spathulenol (Figure $8 \mathrm{p}$ ) putatively identified. Previous studies have reported bacterial growth inhibitory activities for many sesquiterpenoids including caryophyllene, ${ }^{38}$ copaene, epicubenol and cubenene, ${ }^{39}$ elemene and T-cadinol ${ }^{40}$ against a wide panel of pathogenic bacteria, with MIC values as low as $4 \mu \mathrm{g} / \mathrm{mL}$ reported. Several of these inhibitory compounds were also detected in the C. maritima ethyl acetate extract. Thus, sesquiterpenoids are likely to contribute to the growth inhibitory activity determined in our study.

Several monoterpenoids were also detected in the C. maritima ethyl acetate extract. Comparison to a commercial database resulted in putative identification of homomyrtenol (Figure 8a), D-limonene (Figure 8b), linalool (Figure 8c), levomenthol (Figure 8d) and myristicin (Figure 8o). Monoterpenes have been reported to exert a wide variety of biological effects including antibacterial, antifungal, anti-inflammatory and antitumour activities ${ }^{41}$ and therefore are likely to contribute to the growth inhibitory activity against the bacterial triggers of the autoimmune diseases reported here. Indeed, many of the monoterpenoids putatively identified in our study have been previously reported to have potent broad spectrum antibacterial activity. ${ }^{41}$ Further studies have reported that a wide variety of monoterpenoids inhibit the growth of an extensive panel of pathogenic and food spoilage bacteria. ${ }^{42}$ 
Omer et al.: C. maritima inhibits the bacterial triggers of selected autoimmune diseases

Interestingly, several of these monoterpenoids have also been reported to suppress NF- $\kappa$ Bsignaling (the major regulator of inflammatory diseases). ${ }^{43-46}$ Thus, the monoterpenoid components may have a pleuripotent mechanism in blocking the autoimmune inflammatory diseases and relieving its symptoms by acting on both the initiator and downstream inflammatory stages of the disease. Further phytochemical evaluation studies and bioactivity driven isolation of active components are required to further evaluate the mechanism(s) of bacterial growth inhibition.

Despite triterpenoids being detected in all C. maritima extracts (albeit, in low abundances) in the qualitative screenings, no triterpenoids (nor diterpenoids or sesterterpenoids) were detected by GC-MS headspace analysis. It is perhaps not surprising that triterpenoids were not detected as a mass range cut off of $450 \mathrm{~m} / \mathrm{z}$ was used in these studies. Therefore, many triterpenoids would have molecular masses that would be near this cut off and may not be detected. However, given the diversity of other terpenoids detected, it is perhaps surprising that no di-and sesterterpenoids were detected in the extract. Due to the low polarity of these compounds, perhaps an analysis of the lower polarity hexane extract may have detected these classes of phytochemical.

Notably, GC-MS analysis techniques such as those used in our study are limited to the detection of the lower polarity compounds. Therefore, it is likely that mid and high polarity compounds are present in these extracts and these compounds may also contribute to the growth inhibitory activity reported here. HPLC-MS is a good choice for the detection of mid-highly polar compounds. Thus, further studies are required, focussing on these techniques, to build a more comprehensive understanding of the complete metabolomic profile of the C. maritima extracts. Furthermore, mass spectral techniques are generally not capable on their own of differentiating between structural isomers. Further studies using a wider variety of techniques are required to confirm the identity of the compounds putatively identified here.

Whilst these studies have demonstrated the potential of C. maritima extracts to treat autoimmune disease, more work is required. This study has only tested these extracts against some microbial triggers of 3 autoimmune diseases (rheumatoid arthritis, ankylosing spondylitis and multiple sclerosis). The microbial triggers for several other autoimmune inflammatory disorders are also known. For example, Borrelia burgdorferi is linked with Lyme disease. ${ }^{14}$ Whilst microbial triggers have also been postulated for lupus, the specific causative agents are yet to be identified. Similarly, members of the Enterobacteriaceae family are associated with Graves' disease and Kawasaki syndrome. Mycoplasma pneumoniae is associated with several demyelinating diseases. ${ }^{15}$ It would be interesting to extend our studies to also screen for the ability of the extracts to block these microbial triggers of autoimmune diseases. Of further note, our findings also indicate that the C. maritima extracts examined in this study were nontoxic towards Artemia franciscana. All extracts had $\mathrm{LC}_{50}$ values substantially in excess of $1000 \mu \mathrm{g} / \mathrm{mL}\left(\mathrm{LC}_{50}\right.$ values $\geq 1000 \mu \mathrm{g} / \mathrm{mL}$ are defined as nontoxic). ${ }^{34}$

\section{CONCLUSION}

The results of this study demonstrate the potential of C. maritima extracts (particularly the ethyl acetate extract) to inhibit the growth of some bacterial species associated with the induction of selected autoimmune inflammatory diseases. Furthermore, all antibacterial extracts were nontoxic in the Artemia nauplii bioassay, indicating their safety for therapeutic usage. A number of interesting compounds which may contribute to the growth inhibitory properties of the C. mariti$m a$ ethyl acetate extract were putatively identified by GC-MS. Further studies aimed at isolating the inhibitory compounds and identifying their antimicrobial mechanisms are needed.

\section{ACKNOWLEDGEMENTS}

Financial support for this work was provided by the Environmental Futures Research Institute and the School of Natural Sciences, Griffith University and the National Research Centre, Giza, Egypt.

\section{CONFLICT OF INTEREST}

The authors report no conflicts of interest.

\section{ABBREVIATION USED}

DMSO: Dimethyl sulfoxide; $\mathbf{L C}_{50}$ : The concentration required to achieve $50 \%$ mortality, MIC: Minimum inhibitory concentration.

\section{REFERENCES}

1. Meot-Duros L, Le Floch G, Magné C. Radical scavenging, antioxidant and antimicrobial activities of halophytic species. Journal of Ethnopharmacology. 2008;116(2):258-62.

2. Guil-Guerrero JL, Giménez-Martinez JJ, Torija-Isasa ME. Nutritional composition of wild edible crucifer species. Journal of Food Biochemistry. 1999;23(3):283-94.

3. Halliwell B, Gutteridge MCJ. Free radicals in biology and medicine. $3^{\text {rd }}$ ed., Oxford University Press, Oxford; 1999.

4. Gey KF. Cardiovascular disease and vitamins: concurrent correction of 'suboptimal' plasma antioxidant levels may, as an important part of the 'optimal' nutrition, help to prevent early stages of cardiovascular disease and cancer respectively. Bibliotheca Nutritio et Dieta. 1995;52:75-91.

5. Courtney R, Sirdaarta J, Matthews B, et al. Tannin components and inhibitory activity of Kakadu plum leaf extracts against microbialtriggers of autoimmune inflammatory diseases. Pharmacognosy Journal. 2015;7(1):18-31.

6. Sirdaarta J, Matthews B, White A, et al. GC-MS and LC-MS analysis of Kakadu plum fruit extracts displaying inhibitory activity against microbialtriggers of multiple sclerosis. Pharmacognosy Communications. 2015;5(2):100-15.

7. Sirdaarta J, Matthews B, Cock IE. Kakadu plum fruit extracts inhibit growth of the bacterial triggers of rheumatoid arthritis: Identification of stilbene and tannin components. Journal of Functional Foods. 2015;17:610-620.

8. Sautron C, Cock IE. Antimicrobial activity and toxicity of Syzygium australe and Syzygium leuhmannii fruit extracts. Pharmacognosy Communications. 2014;4(1):53-60.

9. Winnett V, Boyer $\mathrm{H}$, Sirdaarta J, et al. The potential of Tasmannia lanceolata as a natural preservative and medicinal agent: Antimicrobial activity and toxicity. Pharmacognosy Communications. 2014;4(1):42-52.

10. Alataha D, Kapral T, Smolen JS. Toxicity profiles of traditional disease modifying antirheumatic drugs for rheumatoid arthritis. Ann Rheum Dis. 2003;62(5):482-6.

11. Ebringer A, Rashid T. Rheumatoid arthritis is an autoimmune disease triggered by Proteus urinary tract infection. Clin Develop Immunol. 2006;13(1):41-8.

12. Ebringer $A$, Cunningham $P$, Ahmadi K. Sequence similarity between HLA-DR1 and DR4 subtypes associated with rheumatoid arthritis and Proteus/Serratia membrane haemolysins. Ann Rheum Dis. 1992;51(11):1245-6.

13. Hughes LE, Smith PA, Natt RS. Cross-reactivity between related sequences found in Acinetobacter sp., Pseudomonas aeruginosa, myelin basic protein and myelin oligodendrocyte glycoprotein in multiple scherosis. J Neuroimmunol. 2003;144(1):105-15.

14. Beermann C, Wunderli-Allenspach H, Groscurth P. Lipoproteins from Borrelia burgdorferi applied in liposomes and presented to dendritic cells induce CD8+ T-lymphocytes in vitro. Cell Immunol. 2000;201(2):124-31.

15. Kollef MH, West S, Davis DR. Central and peripheral nervous system demyelination after infection with Mycoplasma pneumoniae. Evidence of an autoimmune process. Southern Med J. 1991;84(10):1255-8.

16. Cock I, van Vuuren SF. Anti-Proteus activity of some South African medicinal plants: their potential for the prevention of rheumatoid arthritis. Inflammopharmacology. 2014;22(1):23-36. doi:10.1007/ s10787-013-0179-3

17. Nepom GT, Byers P, Seyfried C. HLA genes associated with rheumatoid arthritis. Arthritis Rheum. 1989;32(1):15-21.

18. Wilson C, Ebringer A, Ahmadi K. Shared amino acid sequences between major histocompatibility complex class II glycoproteins, type XI collagen and Proteus mirabilis in rheumatoid arthritis. Ann Rheum Dis. 1995;54(3):216-20.

19. Schwimmbeck PL, Yu DTY, Oldstone MBA. Auto-antibodies to HLA-B27 in the sera of HLA-B27 patients with ankylosing spondylitis and Reiter's syndrome: molecular mimicry with Klebsiella pneumoniae as a potential mechanism of autoimmune disease. J Exp Med. 1987;166(1):173-81.

20. Ebringer A, Rashid T, Wilson C. Ankylosing spondylitis as an auto-immune disease linked to intestinal Klebsiella infection: prospects for a new therapeutic approach. Curr Rheum Rev. 2006;2(4):55-68.

21. Fielder M, Pirt SJ, Tarpey I. Molecular mimicry and ankylosing spondylitis: possible role of a novel sequence in pullulanase of Klebsiella pneumoniae. 
FEBS Lett. 1995;369(2-3):243-8.

22. Ebringer $A$, Hughes $L$, Rashid T. Acinetobacter immune response in multiple sclerosis. Etiopathogenetic role and its possible use as a diagnostic marker. JAMA Neurol. 2005;62(1):33-6.

23. Ebringer $\mathrm{A}$, Rashid $\mathrm{T}$, Wilson $\mathrm{C}$. The role of Acinetobacter in the pathogenesis of multiple sclerosis examined by using Popper sequences. Med Hypoth. 2012:78(6):763-9.

24. RashidT, Ebringer A. Autoimmunity in rheumatic diseases is induced by microbial infections via crossreactivity or molecular mimicry. Autoimmune Dis 2012 Article ID 539282: DOI: 10.1155/2012/539282.

25. Cock IE, Kukkonen L. An examination of the medicinal potential of Scaevola spinescens: Toxicity, antibacterial, and antiviral activities. Pharmacognosy Research. 2011;3(2):85-94

26. Cock IE. Antimicrobial activity of Callistemon citrinus and Callistemon salignus methanolic extracts. Pharmacognosy Communications. 2012;2(3):5-57.

27. Kalt FR, Cock IE. Gas chromatography-mass spectroscopy analysis of bioactive Petalostigma extracts: Toxicity, antibacterial and antiviral activities. Pharmacognosy Magazine. 2014;10(37 Suppl):S37-48.

28. Omer E, Elshamy Al, Nassar M, et al. Plantago squarrosa Murray extracts inhibit $\mathrm{CaCO}_{2}$ and HeLa human carcinoma cell growth: GC-MS analysis of an antiproliferative extract. Pharmacognosy Journal 2016; in progress.

29. Boyer $\mathrm{H}$, Cock IE. Evaluation of the potential of Macadamia integriflora extracts as antibacterial food agents. Pharmacognosy Communications. 2013;3(3):53-62.

30. Arkhipov A, Sirdaarta J, Rayan P, et al. An examination of the antibacterial, antifungal, anti-Giardial and anticancer properties of Kigelia africana fruit extracts. Pharmacognosy Communications. 2014;4(3):62-76

31. Chikowe G, Mpala L, Cock IE. Antibacterial activity of selected Australian Syzygium species. Pharmacognosy Communications. 2013;3(4):77-83.

32. Sirdaarta J, Cock IE. Vitamin $\mathrm{E}$ and Trolox ${ }^{\mathrm{TM}}$ reduce toxicity of Aloe barbadensis Miller juice in Artemia franciscana nauplii but individually are toxic at high concentrations. Internet Journal of Toxicology. 2008;5(1).

33. Ruebhart DR, Wickramasinghe W, Cock IE. Protective efficacy of the antioxidants vitamin E and Trolox against Microcystis aeruginosa and microcystin-LR in Artemia franciscana nauplii. Journal of Toxicologyand Environmental Health Part A. 2009;72(24):1567-75.
34. Cock IE, Ruebhart DR. Comparison of the brine shrimp nauplii bioassay and the ToxScreen-II test for the detection of toxicity associated with Aloe vera (Aloe barbadensis Miller) leaf extract. Pharmacognosy Research. 2009;1(2):102-8.

35. Biggs I, Sirdaarta J, White A, et al. GC-MS analysis of frankincense extracts which inhibit the growth of bacterial triggers of selected autoimmune diseases. Pharmacognosy Communications. 2016;6(1):10-22.

36. Biggs I, Sirdaarta J, White A, et al. GC-MS analysis of Commiphora molmol oleo-resin extracts which inhibit the growth of bacterial triggers of selected autoimmune diseases. Pharmacognosy Journal 2016; in press.

37. Cock IE. The early stages of rheumatoid arthritis: New targets for the development of combinational drug therapies. OA Arthritis. 2014;2(1):5.

38. Huang M, Sanchez-Moreiras AM, Abel C. The major volatile organic compound emitted from Arabidopsis thaliana flowers, the sesquiterpene (E)- $\beta$-caryophyllene, is a defense against a bacterial pathogen. New Phytologist. 2012; 193(4):997-1008.

39. Cane DE, Ke N. Epicubenol synthase. Origin of the oxygen atom of a bacterial sesquiterpene alcohol. Bioorganic and Medicinal Chemistry Letters. 2000; 10(2):105-107.

40. Rahman MM, Garvey M, Piddock LJV. Antibacterial terpenes from the oleoresin of Commiphora molmol (Engl.). Phytotherapy Research. 2008;22(10):1356-60.

41. Cock IE. The phytochemistry and chemotherapeutic potential of Tasmannia lanceolata (Tasmanian pepper): A review. Pharmacognosy Communications. 2013;3(4):13-25.

42. Bakkali F, Averbeck S, Averbeck D. Biological effects of essential oils-A review. Food and Chemical Toxicology. 2008;46(2):446-75

43. Salminen A, Lehtonen M, Suuronen T. Terpenoids: Natural inhibitors of NF-kB signalling with anti-inflammatory and anticancer potential. Cell and Molecular Life Sciences. 2008;65(19):2979-99.

44. Lu XG, Zhan LB, Feng BA. Inhibition of growth and metastasis of human gastric cancer implanted in nude mice by d-limonene. World Journal of Gastroenterology. 2004;10(14):2140-4

45. Crowell PL. Prevention and therapy of cancer by dietary monoterpenes. Journal of Nutrition. 1999;129(3):775S-877S.

46. Zhou JY, Tang FD, Mao GG. Effect of a-pinene on nuclear translocation of NF-kB in THP-1 cells. Acta Pharmacologica Sinica. 2004;25(4):480-4.

\section{PICTORIAL ABSTRACT}

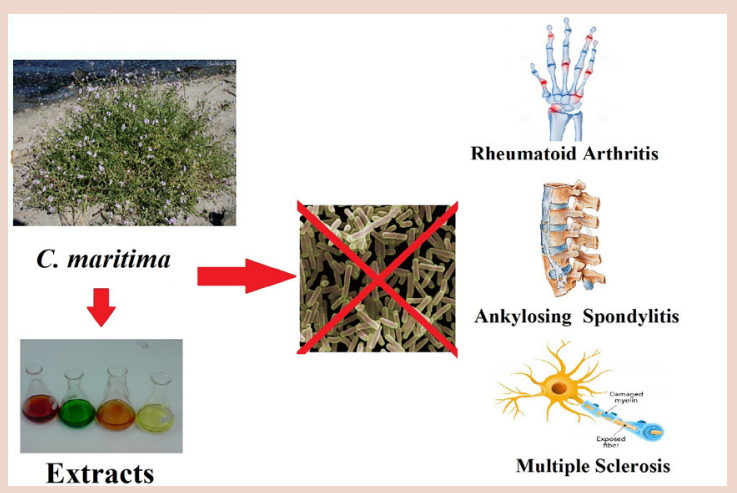

\section{SUMMARY}

- Rheumatoid arthritis may be triggered by P. mirabilis; ankylosing spondylitis by $K$. pneumoniae; and multiple sclerosis by $A$. baylyi and $P$. aeruginosa.

- C. maritima solvent extracts inhibited these microbial triggers of autoimmune disease in vitro.

- The C. maritima ethyl acetate and hexane extract was the most potent ( $\mathrm{MIC}$ between 400 and $800 \mu \mathrm{g} / \mathrm{mL}$ against Proteus spp. and P. aeruginosa).

- The other extracts also inhibited bacterial growth, albeit with lower efficacy.

- All C. maritima extracts were non-toxic in the the Artemia franciscana bioassay

- Phytochemical profiling highlighted several nonpolar compounds as potentially contributing to the growth inhibitory activity of the C. maritima ethyl acetate extract.

\section{ABOUT AUTHORS}

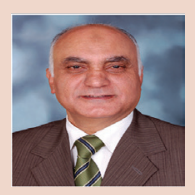

Prof Elsayed A. Omer: Professor Elsayed Omer holds the position of Emeritus Professor of Medicinal and Aromatic Plants at the National Research Centre, Giza, Egypt. He is the head of the Arab Society of Medicinal Plant Research, a member of the Egyptian Society of Horticulture, American Society of Horticulture, Japan Society for Bio-Science, GA Society and the Society for the Conservation of Medicinal Plants in Sinai. He has published 110 peer reviewed publications in highly regarded international journals and has won several prestigious scientific awards. His research focuses on horticultural aspects of Egyptian medicinal and aromatic plants, as well as chemical and biological characterization of their essential oils, natural products, bioactive constituents and the conservation of wild medicinal plants.

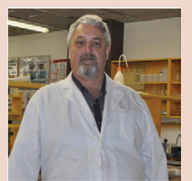

Dr lan Cock: Dr lan Cock leads a research team in the Environmental Futures Research Institute and the School of Natural Sciences at Griffith University, Australia. His research involves bioactivity and phytochemical studies into a variety of plant species of both Australian and international origin including Aloe vera, South Asian and South American tropical fruits, as well as Australia plants including Scaevola spinescens, Pittosporum phylliraeoides, Terminalia ferdinandiana (Kakadu plum), Australian Acacias, Syzygiums, Petalostigmas and Xanthorrhoea johnsoniilgrass trees). This range of projects has resulted in nearly 200 scientific publications in a variety of peer reviewed journals. 